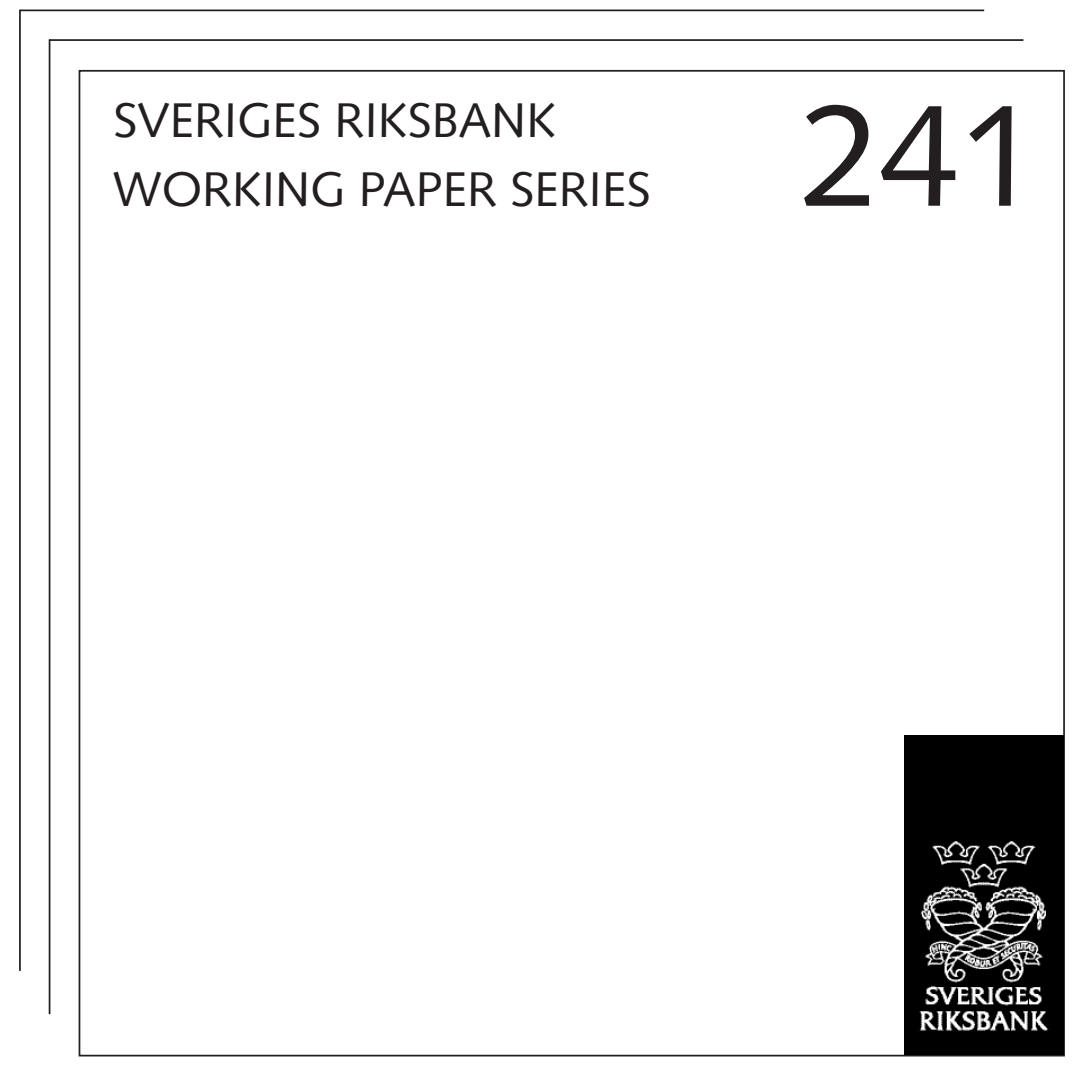

\title{
Monetary Regime Change and Business Cycles
}

Vasco Cúrdia and Daria Finocchiaro

APRIL 2010 


\section{WORKING PAPERS ARE OBTAINABLE FROM}

Sveriges Riksbank •Information Riksbank • SE-103 37 Stockholm Fax international: +4687870526

Telephone international: +4687870100

E-mail: info@riksbank.se

The Working Paper series presents reports on matters in the sphere of activities of the Riksbank that are considered to be of interest to a wider public.

The papers are to be regarded as reports on ongoing studies and the authors will be pleased to receive comments.

The views expressed in Working Papers are solely the responsibility of the authors and should not to be interpreted as reflecting the views of the Executive Board of Sveriges Riksbank. 


\title{
Monetary Regime Change and Business Cycles*
}

\author{
Vasco Cúrdia \\ Federal Reserve Bank of New York \\ Daria Finocchiaro ${ }^{\dagger}$ \\ Sveriges Riksbank \\ Sveriges Riksbank Working Paper Series No. 241
}

April 2010

\begin{abstract}
This paper analyzes to what extent changes in monetary policy regimes influence the business cycle in a small open economy and investigates the impact of policy breaks on the estimation procedure. We estimate a DSGE model on Swedish data, explicitly taking into account the monetary regime change in 1993, from exchange rate targeting to inflation targeting. The results suggest that monetary policy reacted strongly to exchange rate movements in the former, and mostly to inflation in the latter. The external sector plays an important role in the economy and the international transmission mechanism is significantly affected by the choice of exchange rate regime. A counterfactual experiment that applies the inflation targeting policy rule on the disturbances from the exchange rate targeting period suggests that such a policy would have led to higher output and employment, but also to a depreciated currency, higher inflation and a more volatile economy. We also show evidence that ignoring the break in the estimation leads to spurious results for both the parameters associated with monetary policy as well as those that are policy-independent. (JEL: C1, C5, E5, F4)
\end{abstract}

Keywords: Bayesian estimation, DSGE models, target zone, inflation targeting, regime change

\footnotetext{
*An early version of this paper was previously circulated as "An Estimated DSGE Model for Sweden with a Monetary Regime Change." We are indebted to Jesper Lindé, Torsten Persson, Christopher Sims and Lars E.O. Svensson for extensive advice. We would also like to thank Mikael Carlsson, Carlos Carvalho, Efrem Castelnuovo, Marco Del Negro, Giovanni Favara, Jordi Mondria, Virginia Queijo von Heideken, Ulf Söderström, Andrea Tambalotti and Karl Walentin for fruitful discussions and comments. The views expressed in this paper are solely the responsibility of the authors and should not be interpreted as reflecting the views of the Executive Board of Sveriges Riksbank, the Federal Reserve Bank of New York or the Federal Reserve System. Any errors or omissions are the responsibility of the authors.

†Corresponding author. E-mail address: daria.finocchiaro@riksbank.se
} 


\section{Monetary Regime Change and Business Cycles}

\section{Introduction}

After the breakdown of the Bretton-Woods system, several countries searched for a new nominal anchor for their monetary policy. Many small open economies initially opted for some form of managed exchange-rate regimes but, over time, most proved to be incapable of resisting the pressures of international capital markets. As those regimes proved to be inefficient, monetary authorities searched for a new anchor for the conduct of monetary policy. Inflation targeting eventually became the new regime of choice, initially adopted by New Zealand and quickly followed by others, such as Canada, United Kingdom and Sweden. More than two decades after inflation targeting came into being, it is time to evaluate to which extent such changes in monetary policy regime influence our view of economic dynamics.

From a methodological point of view, dealing with regime breaks is not a trivial task. In this paper, we propose a simple method to estimate a model over a period of time containing a regime shift. We then evaluate to which degree it is relevant to explicitly acknowledge the break in the estimation procedure. To be precise, we are not engaging in an exercise in which we are searching for the structural break. In this case we know for a fact that the regime change took place and we further know the precise date of such an event. Therefore, the whole exercise comes down to discussing the extent to which it is important to incorporate that regime break in the estimation procedure or not.

We look at Sweden as a good example of a small open economy that went through a monetary policy regime change. Sweden adopted an exchange rate target zone in 1977, setting a central parity for the Swedish krona against a basket of currencies, and only allowing small deviations from that parity. After the dramatic and unsuccessful attempt to defend the currency at the end of 1992, the Swedish authorities decided to abandon that exchange rate regime. Shortly thereafter, in January of 1993, Sveriges Riksbank (the central bank of 


\section{Monetary Regime Change and Business Cycles}

Sweden) announced the adoption of an inflation targeting regime. ${ }^{1}$

To analyze how the economic dynamics changed from one regime to the other, we estimate a small open economy dynamic stochastic general equilibrium (DSGE) model on Swedish data. Our main goals are to estimate the different monetary policy regimes during the target zone (TZ) period and the inflation targeting (IT) period, analyze how differences in monetary policy affected business cycle dynamics and quantify the extent to which ignoring the break can lead to spurious results in the estimation.

We start by estimating the model assuming that all the parameters in the model are constant in the two sub-periods, except for the monetary policy related ones. ${ }^{2}$ This allows us to estimate two separate policy rules, one for each regime. We compare the propagation of shocks in the two periods through impulse response analysis, and then analyze whether the regime change implies a different decomposition of business cycle volatility. The main conclusion is that the influence of different shocks is very different in the two regimes and, therefore, it is important to account for the regime change in the estimated DSGE in order to properly capture the information in the data.

According to our results, monetary policy reacted strongly to exchange rate movements during the target zone regime while it focused mainly on inflation stabilization during the inflation targeting period. The external sector plays an important role in the open economy and the international transmission mechanism is significantly affected by the choice of exchange rate regime. Moreover, the difference between the two regimes is sharper after shocks that originate abroad. As emphasized in Svensson (1994), the main advantage of a target zone, compared to a fixed peg, is that it gives the monetary authority the ability to

\footnotetext{
${ }^{1}$ After the Bretton Woods collapse in 1973, Sweden participated in the so-called "snake" exchange rate mechanism. In 1977, the Riksbank announced a unilateral target zone to a currency basket constructed using trading weights. In May 1991, the ECU became the official target. Lindbeck et al. (1994), Lindberg et al. (1993), Lindberg and Soderlind (1994) and the official web page of Sveriges Riksbank are good references for a more detailed description of the exchange rate regimes adopted in Sweden in the last century.

${ }^{2}$ As explained at some length in the model section, besides the parameters in the Taylor rule we also allow the risk premium shock in the UIP condition to be regime-dependent.
} 


\section{Monetary Regime Change and Business Cycles}

stabilize the exchange rate without loosing all of its ability to react to domestic shocks. Our results confirm this view. However, foreign shocks hit the economy harder during the TZ period than during the inflation targeting regime because the exchange rate's role as a shock absorber is more restricted. Confirming this view, the contribution of foreign shocks to the business cycle is larger during the target zone regime.

To shed further light on the implications of the two monetary regimes on the business cycles of a small open economy, we also conduct a counterfactual experiment. We evaluate how the inflation targeting monetary policy rule would have performed in response to the shock innovations from the target zone historical sample. In this exercise we find that Sweden would have had significantly higher levels of output, hours and consumption, at the expense of a more depreciated currency (in both nominal and real terms), and inflation would have been on average higher and more volatile. The nominal interest rate would have been lower on average but more volatile as well. In general most variables, other than capital, would have been more volatile.

Finally, it is important to investigate the extent to which ignoring the regime change can lead to spurious results. Therefore we reestimate the model over the whole sample ignoring the policy break and compare the results to our benchmark estimation. We find that in this case we risk capturing business cycle properties that are averaged across the two periods. This misspecification will affect not only the parameters of the policy rule but also the posterior distribution of the parameters that are meant to be structural and independent of the policy regime. This means that we estimate a policy characterization that is not correct for either period and further contaminates the estimation of the policy-independent parameters. In particular, the misspecification affects the parameters associated with the demand side of the economy and, therefore, the whole internal propagation mechanism of the model.

The results discussed in this paper are also important in a wider context because Sweden 


\section{Monetary Regime Change and Business Cycles}

is far from the only country with policy regime changes in recent history. There is a significant number of small open economy countries that experienced policy regime changes in the last thirty years that are well documented, and can thus be subject to the same procedure that we apply to Sweden.

The model in this paper, based on Kollmann (2001), incorporates physical capital, deviations from the law of one price (LOP) and Calvo price and wage setting. As shown by Betts and Devereux (2000), pricing-to-market (PTM) behavior by firms increases nominal and real exchange rate volatility. Considering the empirical failure of the LOP, Kollmann (2001) assumes that intermediate goods firms can price discriminate between domestic and foreign markets and that prices are set in the currency of their customers. To capture the well documented inertia in consumption, we include external habit formation in the utility function. Moreover, we assume frictions in financial markets to create a wedge between the returns on domestic and foreign assets. As in Benigno (2001), this "frictional" risk premium is assumed to be a decreasing function of the country's net foreign asset position.

We consider two different specifications for monetary policy. For the first part of the sample, the target zone period, we partly follow Svensson (1994). A linear managed float without an explicit band is used as an approximation to a non-linear exchange rate band model. In contrast to Svensson (1994), we describe monetary policy by an interest rate rule, whereby the monetary authority reacts to exchange rate deviations from the central parity. For the second part of the sample, in the inflation targeting regime, we describe monetary policy with a Taylor-type rule where the central bank reacts to current inflation, output and, potentially, exchange rate movements.

Seven structural shocks complete the model specification: Shocks to preferences, labor supply, productivity, monetary policy, wage and price markups, and risk premium. ${ }^{3}$ In addi-

\footnotetext{
${ }^{3}$ In a target zone, the exchange rate is allowed to float around the central parity within tight bands. If the pressures on the exchange rate are too strong, the authorities might decide to change the central parity. Therefore, investors form expectations about these changes, and this is what we describe as realignment
} 


\section{Monetary Regime Change and Business Cycles}

tion, three more shocks enter a pre-estimated VAR representing the foreign sector. Following Smets and Wouters (2003), we estimate the model using Bayesian methods.

Structural estimation of small open economy models has been the subject of extensive research in the recent past. Smets and Wouters (2003) showed the advantages of using Bayesian techniques in the estimation of a closed economy model DSGE on Euro Area data. Adolfson et al. (2007) extend that work, applying the same approach on an open economy model for the Euro Area. Other recent papers that estimate open economy models with Bayesian methods include Justiniano and Preston (2010a), Justiniano and Preston (2010b) and Lubik and Schorfheide (2007), among many others.

Unlike the previous literature, this paper considers the effects of monetary regime change on the dynamics of a small open economy. In this way, the paper contributes to the literature on time-varying DSGE models, e.g., Fernández-Villaverde and Rubio-Ramírez (2007) and Justiniano and Primiceri (2008). However, in contrast to those papers, we model a specific change of monetary policy regimes at a given well known date, rather than allowing specific parameters to change over time in a random fashion. Independent work by Adolfson et al. (2008) also considers the change in monetary policy due to the adoption of inflation targeting in Sweden. However, their paper only considers the impact of regime change on the stability of the interest rate rule parameters. Instead, we focus on the overall monetary policy regime, model explicitly the exchange rate targeting regime and evaluate the role of devaluation expectations during the target zone.

The rest of the paper is organized as follows. Section 2 presents the theoretical model. Section 3 describes the estimation procedure and presents the results from the estimation with the regime change in terms of parameter estimates, impulse response functions and

expectations. Usually the pressure is more on the devaluation side and hence we use the terms "realignment expectations" and "devaluation expectations" interchangeably. As will be further discussed in the model description, we assume these expectations to be subject to shocks. These shocks, obviously, only play a role in the target zone period and are incorporated in the risk premium for that period. 


\section{Monetary Regime Change and Business Cycles}

variance decomposition. In section 4, we apply the shock innovations extracted from the target zone historical sample to the estimated system under inflation targeting, while in section 5 we reestimate the model over the whole sample ignoring the break. Section 6 presents our conclusions.

\section{The Model}

The model follows closely Kollmann (2001) who considers a small open economy with a representative household, firms and a government. A single nontradable final good is produced by the domestic country, as well as a continuum of intermediate tradable goods. The final-goods market is perfectly competitive, while there is monopolistic competition in the intermediate goods market. Prices are assumed to be sticky in the buyer's currency. This assumption, commonly denominated as local currency pricing (LCP), is supported by empirical evidence on Swedish exporters' invoicing practice, ${ }^{4}$ and influences the role of the exchange rate in the international transmission mechanism. Specifically, local currency pricing shuts down the expenditure switching effect of the exchange rate in the domestic country. Instead, exchange rate depreciation (appreciation) has a wealth effect on exporters' profits, leading them to raise (decrease) their markups. Thus, in the model, a nominal depreciation improves the domestic country's terms of trade.

The household owns the domestic firms, holds one-period domestic and foreign currency bonds and rents capital to firms. Overlapping wage contracts a la Calvo are assumed. We further consider habit persistence in consumption. The monetary authority follows a Taylortype interest rate rule in both monetary policy regimes. Moreover, following Benigno (2001), we model the risk premium on the return to foreign borrowing as a function of the level of net foreign assets. In the next subsections, we describe each sector of the economy in more

\footnotetext{
${ }^{4}$ See Wilander (2006) and Friberg and Wilander (2007).
} 


\section{Monetary Regime Change and Business Cycles}

detail. For ease of presentation in the text we only set up the agents' optimization problems, leaving the full list of equations (already log-linearized) to Appendix A.

\subsection{Final Goods Production}

A non-tradable final good, $Z_{t}$, is produced in a perfectly competitive market using domestically produced $\left(Q^{d}\right)$ and imported $\left(Q^{m}\right)$ intermediate goods according to the following technology:

$$
Z_{t}=\left(\frac{Q_{t}^{d}}{\alpha^{d}}\right)^{\alpha^{d}}\left(\frac{Q_{t}^{m}}{1-\alpha^{d}}\right)^{1-\alpha^{d}}
$$

where

$$
Q_{t}^{i}=\left[\int_{0}^{1} q_{t}^{i}(s)^{\frac{1}{1+\nu_{t}}} d s\right]^{1+\nu_{t}}, i=d, m
$$

are the domestic and the imported intermediate input quantity indices, $q_{t}^{d}(s)$ and $q_{t}^{m}(s)$ the domestic and imported type " $s$ " intermediate goods and $\nu_{t}$ time varying price markup shock.

Cost minimization implies demand for inputs:

$$
\begin{aligned}
q_{t}^{i}(s) & =Q_{t}^{i}\left(\frac{p_{t}^{i}(s)}{P_{t}^{i}}\right)^{-\frac{1+\nu_{t}}{\nu_{t}}}, i=d, m \\
Q_{t}^{i} & =\alpha^{i} \frac{P_{t} Z_{t}}{P_{t}^{i}}
\end{aligned}
$$

and the price indices are given by:

$$
\begin{aligned}
P_{t}^{i} & =\left[\int_{0}^{1} p_{t}^{i}(s)^{-\frac{1}{\nu_{t}}} d s\right]^{-\nu_{t}}, i=d, m \\
P_{t} & =\left(P_{t}^{d}\right)^{\alpha_{d}}\left(P_{t}^{m}\right)^{1-\alpha_{d}} .
\end{aligned}
$$




\subsection{Intermediate Goods Production}

In the intermediate goods market, a continuum of monopolistic competitive firms combines labor $(L)$ and capital $(K)$ according to the following technology:

$$
y_{t}(s)=\theta_{t} K_{t}(s)^{\psi} L_{t}(s)^{1-\psi},
$$

with

$$
L_{t}(s)=\left[\int_{0}^{1} l_{t}(h ; s)^{\frac{1}{1+\gamma_{t}}} d h\right]^{1+\gamma_{t}}
$$

where $\gamma_{t}$ is a time varying wage markup.

Cost minimization implies

$$
W_{t}=\left[\int_{0}^{1} w_{t}(h)^{-\frac{1}{\gamma_{t}}} d h\right]^{-\gamma_{t}}
$$

where $w_{t}(h)$ denotes the nominal wage of worker $h$, and $W_{t}$ is the price index for labor inputs. The firm's production is sold at both domestic and foreign markets:

$$
y_{t}(s)=q_{t}^{d}(s)+q_{t}^{x}(s) .
$$

Export demand is assumed to have the same form as the domestic demand function,

$$
Q_{t}^{x}=\left(\frac{P_{t}^{x}}{P_{t}^{*}}\right)^{-\eta} Y_{t}^{*}
$$

where $Y_{t}^{*}$ is foreign real GDP and $P_{t}^{*}$ the foreign aggregate price level. Total foreign demand is allocated to the different varieties according to:

$$
Q_{t}^{x}=\left[\int_{0}^{1} q_{t}^{x}(s)^{\frac{1}{1+\nu_{t}}} d s\right]^{1+\nu_{t}}
$$




\section{Monetary Regime Change and Business Cycles}

The demand for each variety is therefore similar to domestic demand:

$$
q_{t}^{x}(s)=Q_{t}^{x}\left(\frac{p_{t}^{x}(s)}{P_{t}^{x}}\right)^{-\frac{1+\nu_{t}}{\nu_{t}}}
$$

with price index:

$$
P_{t}^{x}=\left[\int_{0}^{1} p_{t}^{x}(s)^{-\frac{1}{\nu_{t}}} d s\right]^{-\nu_{t}}
$$

The profits from producing and importing are

$$
\Pi_{t+\tau}^{i}\left(p_{t}^{i}\right)=\left(P_{t+\tau}^{i}\right)^{\frac{1+\nu_{t+\tau}}{\nu_{t+\tau}}} Q_{t+\tau}^{i}\left[\left(p_{t}^{i}\right)^{-\frac{1}{\nu_{t+\tau}}}-S_{t+\tau}^{i}\left(p_{t}^{i}\right)^{-\frac{1+\nu_{t+\tau}}{\nu_{t+\tau}}}\right], \text { for } i=d, m, x
$$

where $S_{t}^{i}$ is the marginal cost. Firms can price discriminate among the domestic and foreign markets and set prices in the currency of the buyer. The firms' profit maximization problem is therefore:

$$
\begin{array}{cl}
\max _{p_{t}^{i}} & \sum_{\tau=0}^{\infty} \alpha_{p}^{\tau} E_{t}\left[\rho_{t, t+\tau} \Pi_{t+\tau}^{i}\left(p_{t}^{i}\right)\right] \\
\text { s.t. } & \Pi_{t+\tau}^{i}\left(p_{t}^{i}\right)=\left(P_{t+\tau}^{i}\right)^{\frac{1+\nu_{t+\tau}}{\nu_{t+\tau}}} Q_{t+\tau}^{i}\left[\left(p_{t}^{i}\right)^{-\frac{1}{\nu_{t+\tau}}}-S_{t+\tau}^{i}\left(p_{t}^{i}\right)^{-\frac{1+\nu_{t+\tau}}{\nu_{t+\tau}}}\right],
\end{array}
$$

where

$$
\rho_{t, t+\tau}=\beta^{\tau} \frac{\xi_{t+\tau} U_{c}(t+\tau)}{\xi_{t} U_{c}(t)} \frac{P_{t}}{P_{t+\tau}}
$$

is the discount factor in domestic currency and $\left(1-\alpha_{p}\right)$ is the probability of being able to set the price in a given period, as implied by the representative household problem described in the following subsection. 


\subsection{The Representative Household}

The representative household $(\mathrm{HH})$ maximizes expected utility: ${ }^{5}$

$$
\begin{array}{ll}
\max & E_{0} \sum_{t=1}^{\infty} \beta^{t} \xi_{t} U\left(C_{t}, L_{t}\right) \\
\text { s.t. } & U\left(C_{t}, L_{t}\right)=\frac{1}{1-\sigma_{c}}\left(C_{t}-v \tilde{C}_{t-1}\right)^{1-\sigma_{c}}-\kappa_{t} \int_{0}^{1} \frac{l_{t}(h)^{1+\sigma_{l}}}{1+\sigma_{l}} d h,
\end{array}
$$

where $l_{t}(h)$ represents the quantity of labor of type $h$ supplied and $\tilde{C}_{t-1}$ past aggregate consumption, taken as exogenous by each individual household. As in Smets and Wouters (2003), we introduce two preference shocks in the utility function: $\xi_{t}$, which affects the intertemporal elasticity of substitution and $\kappa_{t}$, a shock to the disutility of labor relative to the utility of consumption.

The household invests in capital:

$$
K_{t+1}=(1-\delta) K_{t}+I_{t}-\phi\left(K_{t+1}, K_{t}\right)
$$

where the convex adjustment costs are given by

$$
\phi\left(K_{t+1}, K_{t}\right)=\frac{\Phi}{2} \frac{\left(K_{t+1}-K_{t}\right)^{2}}{K_{t}} .
$$

Frictions in financial markets create a wedge between the returns to domestic and foreign assets. As in Benigno (2001), this risk premium is assumed to be a decreasing function of the country's net foreign asset position:

$$
\Omega_{t}=\exp \left\{-\frac{\omega}{2 \Upsilon} \frac{e_{t} B_{t}}{P_{t}}+\zeta_{t}\right\}
$$

where $\zeta_{t}$ is an exogenous shock, and $\Upsilon$ is the steady state value of exports in units of domestic

\footnotetext{
${ }^{5}$ We assume a cashless limit economy as in Woodford (2003).
} 
final goods, $\Upsilon \equiv e P^{x} Q^{x} / P$. This implies that households pay an increasing intermediation premium on their debt. ${ }^{6}$

The budget constraint is:

$$
\begin{aligned}
A_{t}+e_{t} B_{t}+P_{t}\left(C_{t}+I_{t}\right)= & \left(1+i_{t-1}\right) A_{t-1} \\
& +\left(1+i_{t-1}^{*}\right) \Omega_{t-1} e_{t} B_{t-1}+R_{t} K_{t} \\
& +\sum_{i=d, x, m} \int_{0}^{1} \Pi_{t}^{i}(s) d s+\int_{0}^{1} \int_{0}^{1} w_{t}(h) l_{t}(h ; s) d h d s,
\end{aligned}
$$

where $A_{t}$ and $B_{t}$ are stocks of domestic and foreign assets at the end of period $t$. With probability $\left(1-\alpha_{w}\right)$, the household is able to set the wage for type $h$ labor, taking the average wage rate $W_{t}$ as given and satisfying the demand for labor of each type:

$$
l_{t}(h)=\chi_{t} w_{t}(h)^{-\frac{1+\gamma_{t}}{\gamma_{t}}}
$$

where $\chi_{t}=\psi^{-1}(1-\psi)\left(W_{t}\right)^{\frac{1}{\gamma_{t}}} R_{t} K_{t}$.

\subsection{Monetary Authority}

The model accounts for the monetary policy regime shift in Sweden after the 1992 crisis. The data set considered in this paper begins in 1980. Monetary policy between that year and the third quarter of 1992 is best described as a target zone regime. During this first part of the sample, we follow Svensson (1994) by explicitly modeling expectations of realignment and deviations from central parity. However, we depart from that paper by introducing an interest rate rule that takes into account exchange rate deviations form central parity instead of deriving the optimal policy behavior.

\footnotetext{
${ }^{6}$ The financial frictions generate a wedge between borrowing and lending to foreigners. This, together with the assumption that $\beta\left(1+i^{*}\right)=1$, leads to an optimal choice of zero net foreign assets in a non-stochastic steady state.
} 


\section{Monetary Regime Change and Business Cycles}

After the exchange rate crisis in 1992, the Riksbank decided to let the krona float and enter a regime of explicit inflation targeting. In the inflation targeting regime, monetary policy is represented by a simple Taylor-type rule in which the interest rate responds to inflation, output and exchange rate movements. We further augment the policy rule to include interest rate smoothing.

\subsubsection{Target Zone Regime}

Following Svensson (1994), we write the exchange rate as $\hat{e}_{t}=\hat{e}_{c, t}+\hat{e}_{x, t}$, where $\hat{e}_{c, t}$ is the central parity exchange rate and $\hat{e}_{x, t}$ refers to the deviations of the exchange rate from central parity. It follows that expected realignments satisfy:

$$
E_{t}\left[\hat{e}_{t+1}-\hat{e}_{t}\right]=E_{t}\left[\hat{e}_{c, t+1}-\hat{e}_{c, t}\right]+E_{t}\left[\hat{e}_{x, t+1}-\hat{e}_{x, t}\right]
$$

Realignment expectations have an endogenous component, here modeled as a linear response to the exchange rate deviations from central parity, and an exogenous component which follows an $\mathrm{AR}(1)$ process:

$$
\begin{gathered}
E_{t}\left[\hat{e}_{c, t+1}-\hat{e}_{c, t}\right]=g_{t}+\rho_{x} \hat{e}_{x, t} \\
g_{t}=\rho_{g} g_{t-1}+\varepsilon_{g, t}
\end{gathered}
$$

Compared to a fully fixed exchange rate system, a target zone regime gives central banks more flexibility in the management of the exchange rate, thereby allowing monetary policy to be used for other purposes. Nevertheless, the central bank is constrained to using the policy instrument to also keep the exchange rate close to central parity and fight expectations of realignment. Therefore, we represent monetary policy by a modified Taylor rule taking into 


\section{Monetary Regime Change and Business Cycles}

account the reaction to exchange rate deviations from the central parity:

$$
\hat{\imath}_{t}=\rho_{m, T Z} \hat{\imath}_{t-1}+\left(1-\rho_{m, T Z}\right)\left[\Gamma_{p, T Z} \hat{\pi}_{t}+\Gamma_{y, T Z} \hat{Y}_{t} / 4+\Gamma_{x, T Z} \hat{e}_{x, t}\right]+\varepsilon_{m, T Z, t},
$$

where $\hat{\pi}_{t}$ and $\hat{Y}_{t}$ are expressed as percentage deviations from steady state values, $\varepsilon_{m, t}$ is an i.i.d. shock which captures the non-systematic component of monetary policy, and $\hat{\imath}_{t}$ is defined by $\hat{\imath}_{t} \equiv \frac{i_{t}-\bar{\imath}}{1+i_{t}}$, with $\bar{\imath}$ the steady state level of the interest rate. Inserting (2.25) into (2.24), we get an expression for the expectations of depreciation:

$$
E_{t}\left[\hat{e}_{t+1}-\hat{e}_{t}\right]=E_{t} \hat{e}_{x, t+1}+g_{t}-\left(1-\rho_{x}\right) \hat{e}_{x, t} .
$$

With some algebra, it is possible to rewrite the uncovered interest rate parity relation for the target zone period as:

$$
\hat{\imath}_{t}=\hat{\imath}_{t}^{*}+E_{t} \hat{e}_{t+1}+\left(\rho_{x}-1\right) \hat{e}_{t}-\omega \hat{B}_{t}+\zeta_{t, T Z}
$$

where we define

$$
\zeta_{t, T Z} \equiv g_{t}+\zeta_{t}
$$

to highlight the fact that the exogenous component of the expectation of realignment, $g$, appears only in the target zone period. For identification reasons, we choose to estimate the sum $g+\zeta$, and rename it simply as $\zeta_{t, T Z}$. Thus, in what follows, the "risk premium shock" encompasses both a pure "expectations of devaluation" and a "risk premium" component when referring to the target zone regime. To make it clear, for the inflation targeting regime we define similarly

$$
\zeta_{t, I T} \equiv \zeta_{t}
$$

and we allow $\zeta_{t, T Z}$ and $\zeta_{t, I T}$ to follow different stochastic processes (allowing for different 


\section{Monetary Regime Change and Business Cycles}

autocorrelation and volatility).

\subsubsection{Inflation Targeting Regime}

In the inflation targeting period, with the exchange rate freely floating, the monetary authority's actions while steering the economy are no longer constrained. It is reasonable to expect that it might want to achieve greater interest rate smoothing, more aggressiveness in its reaction to inflation and more responsiveness to output fluctuations. This will be part of the empirical question we are trying to address, namely to what extent the target zone limits central bank reactions to inflation and output changes as well as the degree of interest rate smoothing. Moreover, according to the results in Lubik and Schorfheide (2007), the Bank of Canada and the Bank of England include the nominal exchange rate in their policy rules. Hence, we model monetary policy through a standard log-linearized Taylor rule augmented with a response to exchange rate movements:

$$
\hat{\imath}_{t}=\rho_{m, I T} \hat{\imath}_{t-1}+\left(1-\rho_{m, I T}\right)\left[\Gamma_{p, I T} \hat{\pi}_{t}+\Gamma_{y, I T} \hat{Y}_{t} / 4+\Gamma_{x, I T} \Delta \hat{e}_{t}\right]+\varepsilon_{m_{I T}, t} .
$$

Note that the coefficients in the two Taylor rules, in equation (2.27) and (2.32), are regimedependent; hence we allow for different responses of the monetary authority to inflation, output, exchange rate and interest rate in the two regimes. Moreover, the variance of the monetary policy shock is allowed to vary across the two subsamples. 


\section{Monetary Regime Change and Business Cycles}

\subsection{Foreign Sector}

For simplicity, we treat the foreign sector as exogenous and assume that foreign output, inflation and interest rate follow a log-linear VAR model with one lag:

$$
G_{0}\left[\begin{array}{c}
\hat{Y}_{t}^{*} \\
\hat{\pi}_{t}^{*} \\
\hat{\imath}_{t}^{*}
\end{array}\right]=G_{1}\left[\begin{array}{c}
\hat{Y}_{t-1}^{*} \\
\hat{\pi}_{t-1}^{*} \\
\hat{\imath}_{t-1}^{*}
\end{array}\right]+\left[\begin{array}{c}
\varepsilon_{y, t}^{*} \\
\varepsilon_{p, t}^{*} \\
\varepsilon_{i, t}^{*}
\end{array}\right] .
$$

We pre-estimate the foreign VAR using standard OLS methods and keep these parameters fixed through the estimation of the DSGE model.

\subsection{Equilibrium}

The equilibrium in the domestic goods market requires that

$$
\begin{aligned}
Z_{t} & =C_{t}+I_{t} \\
K_{t} & =\int_{0}^{1} K_{t}(s) d s .
\end{aligned}
$$

It is assumed that no foreigners hold domestic assets, so that in equilibrium:

$$
A_{t}=0
$$

Finally, in equilibrium, it is possible to recover the Balance of Payments equation from the budget constraint:

$$
B_{t}=\left(1+i_{t-1}^{*}\right) \Omega_{t-1} B_{t-1}+P_{t}^{x} Q_{t}^{x}-P_{t}^{*} Q_{t}^{m}
$$




\subsection{Shock Structure}

There are seven structural shocks in the economy: shocks to preferences, productivity, the risk premium, labor supply, the Taylor rule, the price markup and the wage markup. The first four follow stochastic processes given by:

$$
z_{t}=\left(1-\rho_{z}\right)+\rho_{z} z_{t-1}+\varepsilon_{z, t}
$$

while the two markup shocks and the monetary shock are i.i.d. and take the form:

$$
z_{t}=z+(1+z) \varepsilon_{z, t}
$$

The shock structure is completed by three additional shocks - shocks to foreign inflation, output and interest rate - that are included in the pre-estimated exogenous foreign VAR.

The full model is solved and estimated in log-linear form around its deterministic steady state. $^{7}$

\section{Estimation With Regime Change}

We estimate the model using Bayesian techniques and explicitly incorporate the monetary policy regime change to analyze the extent to which the policy break influences the estimated results. More precisely, we rewrite the system in state-space form representation for each period/regime and match the observables with latent variables through a system of observation equations to construct the likelihood of the model. ${ }^{8}$ Combining our priors, described in the next subsection, with the likelihood, we form the posterior density and

\footnotetext{
${ }^{7}$ We solve the model using the Matlab routine gensys.m created by Christopher Sims. The log-linearized equilibrium conditions are presented in Appendix A.

${ }^{8}$ Because the steady state is exactly the same in both regimes, the variables in log-deviations from steady state convey exactly the same interpretation in both regimes, as they are referring to the same steady state.
} 


\section{Monetary Regime Change and Business Cycles}

estimate its mode through numerical optimization methods. Then, we generate a sample of four parallel chains of 200,000 draws using Markov Chain Monte Carlo (MCMC) methods.

To explicitly account for the monetary regime change that occurred after November 1992, when forming the likelihood of the model, we initialize the Kalman filter for the two subsamples differently. Specifically, first we set the state space form for the target zone period initializing the Kalman filter with mean zero and an identity covariance matrix. Then, we eliminate the last observation of the target zone subsample and the first of the inflation targeting to minimize the effects of breaks in expectations in the theoretical model. We restart the Kalman filter for the second subsample with a mean equal to the values of the state variables of the last observation available for the target zone. The covariance matrix is set equal to the covariance matrix in the last period of the first subsample for the state variables that are common in both regimes, but multiplied by a factor of $(1.5)^{2}$ to imply that there is some increase in uncertainty about the filter.

A common problem in highly parametrized models is that it is unfeasible to directly infer the properties of the posterior. Therefore it becomes necessary to employ iterative simulation algorithms. In this paper, we exploit a Metropolis algorithm using a Normal as the jumping distribution. To initialize the MCMC procedure, we use importance resampling. First, we draw a sample of 1,000 simulations from an approximate distribution based on a mixture of Normals with means equal to the posterior mode and variances equal to the inverse Hessian scaled using four different factors. Then, we improve this approximation using importance resampling and using the results as starting points for the Metropolis algorithm. To ensure convergence, we updated the covariance matrix used for the jumping distribution twice. ${ }^{9}$

The data used for the estimation corresponds to ten variables in the model: foreign interest rate, foreign consumer price index (CPI), foreign output, domestic output, domestic

\footnotetext{
${ }^{9}$ The covariance matrix used in the jump distribution is scaled to generate an acceptance ratio of about $23 \%$ for each chain.
} 


\section{Monetary Regime Change and Business Cycles}

CPI, domestic interest rate, nominal exchange rate, real wages, hours worked and consumption. Our data set contains quarterly data over the period 1980q1 - 2008q4. The data refers to Sweden and a foreign sector which is a composite of eight foreign countries among its major trading partners: Denmark, Finland, France, Germany, Italy, Japan, Netherlands, Norway, United Kingdom, and United States. To construct foreign variables, we aggregate national variables according to their trade weights. ${ }^{10}$ All series were seasonally adjusted and detrended using a linear trend prior to estimation. ${ }^{11}$ A more detailed description of the data can be found in Appendix B and Tables 1 and 2.

The first subsection discusses the priors, the second analyzes the posterior and the third and fourth analyze impulse response and variance decomposition respectively.

\subsection{Priors}

In Bayesian estimation, priors fulfill two important purposes. The first is to incorporate information about some of the parameters of interest to narrow down the possible scope of search, thereby allowing for more precise estimation. In this sense, we are applying a strict Bayesian updating on previously available information. The second purpose of priors is to smooth the search and move it away from theoretically unacceptable parameter values (like restricting some parameters to be positive). In setting the priors, we take these two purposes into account. The main properties of our prior distributions are presented in Table 3.

Technology, utility and price setting parameters are assumed to be Normal, Beta (whenever the parameter varies in a range of zero and one), Gamma or Inverse Gamma (whenever parameters are positive). Lindé (2004) calibrates the price elasticity of aggregate exports $(\eta)$

\footnotetext{
${ }^{10}$ In the nominal variables (CPI, interest rate and exchange rate), the US has double weight, in accordance with the actual basket which the Riksbank targeted in the first half of our sample. Given that we have a general equilibrium model, we also use a double weight for prices and interest rates, but not for real output (the driving force behind the real demand for exports). We maintain the same weighting scheme throughout the second part of the sample to keep the model consistent.

${ }^{11}$ Interest rate and exchange rate series were not seasonally adjusted.
} 


\section{Monetary Regime Change and Business Cycles}

for Sweden at 1, referring to the findings of Johansson (1998) who estimates this parameter at 1.3 for manufactured goods and 0.7 for the services sectors. We use a prior distributed as an inverted gamma with mean 1.5 and standard deviation 0.3. Apel et al. (2005) provide a survey of Swedish firms according to which firms change their prices once a year. However, using macro data, both Smets and Wouters (2003) and Adolfson et al. (2007) estimate a higher degree of price rigidity for the Euro area. Therefore, for both Calvo parameters $\alpha_{p}$ and $\alpha_{w}$, we choose a beta distribution with the mode 0.8 and a standard deviation of 0.15 . The prior for the risk aversion parameter is a Normal with mean 2, consistent with the calibrated value used by Kollmann (2001) and the value estimated by Lindé et al. (2009). In Smets and Wouters (2003), the prior for the habit persistence parameter $(v)$ is distributed as a beta with the mean 0.70, while Adolfson et al. (2007) have a prior with a lower mean, 0.65. We choose a beta with a mean of 0.7 and a standard deviation of 0.1 . As for the other utility parameter, the inverse elasticity of labor supply $\left(\sigma_{l}\right)$, we chose a normal with mean 1 . For the adjustments cost parameter $\Phi$, we use a gamma with a mean of 10 and a standard deviation of 5 to encompass the values used in Kollmann (2001). Lane and Milesi-Ferretti (2001) regress the interest rate differential on NFA/exports and estimate the financial frictions at 2.8. In our model, this would correspond to a $\omega$ of 0.0035 , so this was used as the mode for our prior. ${ }^{12}$

We consider identical priors for the monetary policy rule parameters for both periods. More precisely, we assume $\Gamma_{p}$ and $\Gamma_{y}$ to be distributed according to gammas with means of 2 and 0.5 , respectively. The prior for the interest rate smoothing parameter $\left(\rho_{m}\right)$ is distributed as a beta with a mean of 0.8 . The Taylor rule parameter on the exchange rate $\left(\Gamma_{e}\right)$ is a truncated normal with a mean of 1.6 and the mode for the coefficient for the endogenous

\footnotetext{
${ }^{12}$ For computational purposes, we rescale several parameters so that the values shown in the posterior tables are for the normalized parameters, $\tilde{\Theta}=\mu \Theta$, where $\mu$ is a scale factor and $\Theta$ are the model parameters. To be precise we consider $\mu_{\omega}=1 / 100, \mu_{\sigma_{m}}=1 / 100, \mu_{\sigma_{\xi}}=1 / 10, \mu_{\sigma_{\theta}}=1 / 100, \mu_{\sigma_{\kappa}}=1 / 1000, \mu_{\sigma_{\nu}}=1 / 100$, $\mu_{\sigma_{\gamma}}=1 / 100$, and $\mu_{\sigma_{\zeta}}=1 / 100$. This is why, for example, in Table 3 the prior median of $\omega$ is 0.34 , instead of 0.0034 .
} 


\section{Monetary Regime Change and Business Cycles}

part in the realignment expectations $\left(\rho_{x}\right)$ is set at 0.20 . These last two parameters are to some extent based on the theoretical experiments and empirical analysis by Svensson (1994).

All variances of the structural shocks are assumed to be distributed as inverted Gammas, with a normalized mean and loose variance. Finally, we assume the autocorrelation coefficients of the shocks to follow a beta with a mean of 0.8 and a standard deviation of 0.15 .

We choose to calibrate some parameters that are related to steady state levels and therefore difficult to pin down in our detrended data. More precisely, we set the discount factor, $\beta$, at 0.99 and the depreciation rate, $\delta$, at 0.025 . The fraction of the final goods expenditure that is made on domestic goods, $\alpha^{d}$, is calibrated to match the implied steady state imports GDP ratio in the two subsamples. The technology parameter, $\psi$, is calibrated at 0.3, consistent with the value used in Lindé (2004) and Smets and Wouters (2003). As in Kollmann (2001), we refer to the estimates of Martins et al. (1996) to calibrate the steady state markup over marginal cost for intermediate good, $\nu$, at 0.16 , a value in line with the estimate for the manufacturing sector in Sweden.

\subsection{Parameter Posteriors}

The first question that we ask in this paper is whether there are significant differences in monetary policy under the target zone and inflation targeting regimes. In order to answer that we start by analyzing the posterior of the parameters, with a special focus on those related to the regime change. Table 3 displays a comparison of prior with posterior moments. ${ }^{13}$ The first two panels show parameters that are constant across regimes while the lower two

\footnotetext{
${ }^{13}$ We monitored convergence by estimating the potential scale reduction $(\hat{R})$, and the effective number of independent draws for the group of five chains $\left(m n_{e f f}\right)$ as suggested in Gelman et al. (2004). To monitor for within chain convergence, we followed the methods proposed in Geweke (1999) to compute the effective number of independent draws $\left(n_{e f f}\right)$. We complemented these tests with the separated partial means test also proposed in that paper as well as a graphical analysis. These statistics are not presented but are available upon request.
} 


\section{Monetary Regime Change and Business Cycles}

panels show the parameters associated with each regime.

The estimated monetary policy rules show interesting differences between the target zone and the inflation targeting regimes. Consistent with a priori expectations, in the target zone the central bank reacted strongly to exchange rate deviations from central parity while under inflation targeting monetary policy focused mainly on inflation stabilization. According to our results, monetary policy responded much more aggressively to exchange rate movements during the target zone period than during the inflation targeting period. During the target zone regime, $\Gamma_{e, T Z}$ has a median of 1.3 - taking into account the interest rate smoothing parameter, our estimate implies that a $1 \%$ deviation of the exchange rate from central parity would lead, ceteris paribus, to a 91 basis point increase in the policy rate. In contrast, in the inflation targeting regime a $1 \%$ quarterly change in the nominal exchange rate would move the annualized interest rate by less than one basis point, a remarkable difference in response.

The estimated response of monetary policy to inflation is somewhat stronger during the inflation targeting regime (median of 2.06) than during the target zone period (median of 1.78). Interestingly, policy reacted to some extent to output during the target zone period (median of 0.66), but almost not at all in the period of inflation targeting (median of 0.01). Thus, according to our estimation, during the inflation targeting period, monetary policy is more focused on responding to inflation than responding to movements in the real economy. This finding is consistent with the Sveriges Riksbank Act, which states that the objective of monetary policy is to "maintain price stability" and suggests an attempt to rebuild credibility and gain the confidence of the general public. ${ }^{14}$

As expected, we estimate a lower value for the interest rate smoothing coefficient during the target zone regime (median of 0.82 ) than during the inflation targeting period (median

\footnotetext{
${ }^{14}$ In more recent documents of the Riksbank, output concerns are considered only gradually, as credibility is being built. Heikensten and Vredin (1998), for example, stress that there is no conflict between the longterm objective, price stability, and the mitigation of short-run output fluctuations only as long as "inflation target credibility is not weakened".
} 


\section{Monetary Regime Change and Business Cycles}

of 0.90$)$. The non-systematic component in the Taylor rule $\left(\varepsilon_{m, t}\right)$ is almost 4 times more volatile during the target zone period than during the inflation targeting period. These

results are consistent with the findings in Adolfson et al. (2008), and suggest that monetary policy has become more predictable and systematic after the introduction of the inflation targeting regime. Another coefficient of significant interest is the sensitivity of the expected rate of realignment, $\rho_{x}$, with a posterior median of 0.35 , a value close to the estimates in Svensson (1994). The combined shock to realignment expectations and risk premium shock in the target zone is both less persistent and less volatile than the risk premium shock in the inflation targeting regime.

As for other, regime independent parameters, shown in the top two panels, our posterior moments are in the ballpark of previous studies with a few exceptions. The price elasticity of foreign demand for the domestic good, $\eta$, is estimated at 1.76 , thus above the values estimated by Johansson (1998), but lower than the 3.0 obtained by Gottfries (2002). The Calvo parameters, $\alpha_{p}$ and $\alpha_{w}$, have medians of 0.85 and 0.95 , thus implying that prices are more flexible than wages in Sweden. This result is at odds with the results of Adolfson et al. (2008) for Sweden and Smets and Wouters (2003) for the Euro area. However, those two papers assume both price and wage indexation, another source of stickiness, and estimate a higher degree of indexation for wages as compare to prices. For the sake of simplicity, here we assume no indexation to the past for either of the two series. Finally, both the technology and the labour supply shock processes are estimated to be quite persistent, with estimated autocorrelation coefficients of 0.99 .

\subsection{Dynamic Responses}

This subsection analyzes to what extent the two monetary policy regimes estimated for Sweden affect the transmission of different shocks, as measured by the response of some key 


\section{Monetary Regime Change and Business Cycles}

Swedish macro variables. These responses are shown in Figures 1 through $5 .{ }^{15}$. Our results illustrate the importance of correctly formulating the monetary policy regime since it affects sensibly the transmission mechanism of the different disturbances to the economy.

Our main findings are that the external sector plays an important role in the economy and the international transmission mechanism is significantly affected by the choice of exchange rate regime. In particular, the difference in the economic dynamics under the two regimes is sharper in the case of shocks that originate abroad. Responses to foreign shocks are generally stronger in the target zone regime than in the inflation targeting regime since the exchange rate acts as a shock absorber in the latter. As highlighted in our results in Section 5 (discussed below), it is therefore crucial to account for the regime change in our estimated DSGE to properly analyze the business cycle dynamics of a small open economy like Sweden. We analyze some of the responses in more detail below.

An increase in the foreign interest rate (Figure 1) has a considerable negative effect on GDP, employment and capital accumulation in the target zone period, while during inflation targeting period its consequences are much more benign and mild. On the other hand, this shock induces, not surprisingly, a larger real and nominal exchange rate depreciation under inflation targeting. In the inflation targeting regime, the domestic interest rate reacts less to the higher foreign interest rate and lets the domestic currency depreciate. Given our assumption of local currency pricing, a depreciation of the home currency raises the markup of exporting firms. This foreign monetary policy tightening contracts demand abroad but at the same time the resulting depreciation induces a sizable increase in exporters' profits. Exporters are therefore able to charge a lower price and exports increase. This leads to a slight increase in output, employment and inflation. In contrast, during the target zone period, the central bank increases the domestic interest rate more significantly to prevent

\footnotetext{
${ }^{15}$ Responses are presented in percentage points. The shocks are set to one standard deviation. In the plots, we present the median response. For the sake of exposition, we present only six shocks. All the other impulse response functions are available upon request.
} 


\section{Monetary Regime Change and Business Cycles}

a large depreciation. This has contractionary effects and triggers a decrease in output, employment and capital stock. Therefore, the two regimes imply responses that are both qualitatively and quantitatively different.

The risk premium shocks (Figure 2) also have very different effects during the two regimes. The comparison between the two shocks is particularly interesting since, as explained above, in our estimation for the target zone period the risk premium shock also incorporates a realignment expectations component. During the target zone period, the depreciation generated by an increase in the risk premium (or expectations of depreciation) leads the monetary authorities to increase the interest rate, thus generating a contraction in the real economy. In contrast, under inflation targeting, the monetary policy tightening that follows a risk premium shock is more muted. In that case, the increase in exporters' profits induced by the depreciation has an expansionary effect.

A positive labor supply shock (Figure 3) changes the intratemporal substitution between labor and consumption. The shock has similar effects on output, employment and capital accumulation under both monetary regimes. However, the response of inflation differs across the two regimes and this shock leads to stagflation if no action is taken. Indeed, this is what happens in the target zone period; the shock generates a recession and inflation. In

the inflation targeting period, the exchange rate is allowed to change and therefore the necessary real exchange rate adjustment is more immediate. The exchange rate appreciation shrinks exporters' profits more than in the target zone period. As employment contracts, so does consumption. Throughout the entire episode for the two regimes, capital stock falls significantly and very persistently.

A technology shock (Figure 4) generates similar qualitative responses in the two regimes. However, in the inflation targeting period, the domestic currency is allowed to depreciate more, leading to higher interest rates and lower output as compared to the target zone period. In the inflation targeting period, the real exchange rate adjustment is more sizable 


\section{Monetary Regime Change and Business Cycles}

and immediate. Give our assumption about the exporters' invoicing practice, the exchange rate depreciation increases exporters' profits more than in the target zone period.

A monetary shock (Figure 5) is worth mentioning only in that it generates a much stronger response in the inflation targeting period. Even though the size of the shock during this period is about half the one during the target zone period, output response is almost twice as strong. The reason for this is that such a monetary shock destabilizes the exchange rate and, thus, needs to be undone in a target zone regime soon after. In the inflation targeting regime, since exchange rates are free to float and react, exports are more responsive (precisely because export prices change more), as are output and the remaining economy.

\subsection{Sources of Business Cycle Fluctuations}

To analyze to what extent differences in policy regimes affect the sources of business cycle fluctuations, we perform a variance decomposition for output, inflation, interest rate, and nominal and real exchange rates. Tables 4 and 5 show the results, measured in terms of the contribution of each shock to the volatility of each variable, at different horizons of business cycle frequency. ${ }^{16}$

Labor supply shocks are the most significant source of output fluctuations in both regimes and for all of the time horizons considered. In the short run (as measured at one quarter ahead), technology shocks are the second most important source of output fluctuations during the target zone period (accounting for about 13\%). In contrast, in the inflation targeting regime the preference shock is more relevant, accounting for about $20 \%$ of the volatility of real output at a one-quarter horizon while the productivity shock accounts for about $10 \%$. Labor supply shocks may capture unmodelled labor market features or shifts in per capita hours of work due, for example, to demographic changes or fiscal reforms. Our results are in line with Smets and Wouters (2003), who find that labor supply shocks are one of the main

\footnotetext{
${ }^{16}$ Each element of the table presents the median.
} 


\section{Monetary Regime Change and Business Cycles}

sources of output variation for the Euro area.

The risk premium and realignment expectation shocks are both important in explaining real exchange rate and nominal interest rate volatilities in the medium run, in both the target zone and inflation targeting regimes (recall that in the former, the risk premium also includes shocks to realignment expectations). To be precise, at the four-quarter horizon, risk premium shocks account for about $50 \%$ of interest rate and real exchange rate volatility, while during the target zone period risk premium shocks (including shocks to the expectation of realignment) explain up to $18 \%$ and $14 \%$, respectively.

Interestingly, monetary shocks account for a significant part of the real exchange rate fluctuations during the target zone (almost $48 \%$ at 1 quarter ahead, $38 \%$ at 4 quarters ahead and $11 \%$ at 20 quarters ahead), but have only a limited role during the inflation targeting period (always less than 6\%). Price and wage markup shocks explain most of the inflation variation under both monetary regimes in the short and medium run.

Finally, it is worth noting that, consistent with previous DSGE studies, ${ }^{17}$ foreign shocks have only a limited contribution to business cycle fluctuations at every horizon in both regimes. However, their importance is somewhat higher during the target zone period. For example, in the short run their role in explaining output fluctuations is as much as four times larger in the target zone period than in the inflation targeting period.

\section{A Counterfactual Experiment}

To further highlight differences and implications of the two monetary regimes under study for the business cycle of a small open economy, in this section we perform a counterfactual experiment. Namely, we extract the shock innovations from the target zone historical sample and then apply them to the equations in the inflation targeting regime. The idea behind

\footnotetext{
${ }^{17}$ See, e.g., Justiniano and Preston (2010a).
} 


\section{Monetary Regime Change and Business Cycles}

this experiment is to analyze how the variables would react during the target zone period if the policy regime were consistent with the one estimated for the inflation targeting regime. This analysis allows us to consider how different the evolution of the economy would be if the policy regime were the one estimated for the inflation target regime.

In doing this exercise, some caution is needed when it comes to shocks to the monetary policy and the risk premium terms. These shocks are regime-specific, hence capturing these innovations and applying them to the alternative policy regime can be misleading. Therefore the comparison shown in Table 6 and in Figure 6 shuts down the innovations to these two shocks. ${ }^{18}$

The main result to take from this exercise is that applying the IT policy regime to the innovations in the shocks hitting Sweden during the target zone period results in higher levels of output, capital, hours and consumption, at the expense of a more depreciated currency (in both nominal and real terms). Inflation would be on average higher under an IT policy and more volatile. The nominal interest rate would be lower on average but more volatile as well.

It is especially interesting to analyze the second half of the TZ period as inflation started peaking, and the nominal interest rate and output fell somewhat relative to the trend. However, when applying the policy estimated for the IT period, the interest rate increased, although at a slightly lower level, which in turn led to an output level that was much higher relative to the trend and to the result implied by the TZ policy regime. Similarly, consumption was substantially higher in this part of the sample under the policy estimated for the IT period.

On the other hand, the volatility of most variable increased. The only exception was capital, which was less volatile. Notice, however, that the increase in volatility of output and inflation were fairly small, especially in comparison to the increased level of output. It is up

\footnotetext{
${ }^{18}$ Even if we do not shut down these two shocks the results are qualitatively similar.
} 


\section{Monetary Regime Change and Business Cycles}

from discussion which of these is more important from a normative standpoint and greatly depends on the loss function of the policymakers.

\section{Estimation Without Regime Change}

In the previous section we analyzed the differences between the two monetary policy regimes. In this section we turn to the discussion of how much it matters to properly account for the monetary policy regime change in the estimation. To do this, we re-estimate the model over the exact same data, but without the policy regime change from one subperiod to the other, so that in both periods we assume that the regime can be described with the same interest rate rule - which we assume to have the same form as in (2.32), the IT rule. Notice that this also implies no realignment expectations shocks and therefore the risk premium term has the same properties in the two subperiods.

The main goal of this analysis is to evaluate the extent to which ignoring the regime break can lead to spurious results in the estimation of the model.

\subsection{Spurious Parameter Posteriors}

In order to help the discussion, Table 7 presents the median and $90 \%$ interval for both the baseline and the no regime change (NRC) estimations. Ex ante, we should expect that the NRC estimation would yield parameter posteriors for the policy rule that would be a mixture of the posterior for the two regimes in the baseline estimation (the two lower groups of parameters in the table). Furthermore, if the misspecification is not significant then we should expect to get very similar results for the structural parameters that are constant across regimes (the two top panels in the table). The results are shown in Table 7.

Let us begin with the parameters that are regime-dependent, shown in the bottom two panels in the table. Using the median of the posterior distributions, we can write the policy 
rules as:

$$
\begin{aligned}
& T Z: \hat{\imath}_{t}=0.82 \hat{\imath}_{t-1}+0.18\left[1.78 \hat{\Pi}_{t}+0.66 \frac{\hat{Y}_{t}}{4}+1.30 \hat{e}_{x, t}\right]+0.0058 \varepsilon_{m, T Z, t} \\
& I T \quad: \hat{\imath}_{t}=0.90 \hat{\imath}_{t-1}+0.10\left[2.06 \hat{\Pi}_{t}+0.01 \frac{\hat{Y}_{t}}{4}+0.02\left(\hat{e}_{t}-\hat{e}_{t-1}\right)\right]+0.0015 \varepsilon_{m, I T, t} \\
& N R C \quad: \quad \hat{\imath}_{t}=0.85 \hat{\imath}_{t-1}+0.15\left[1.70 \hat{\Pi}_{t}+0.01 \frac{\hat{Y}_{t}}{4}+0.10\left(\hat{e}_{t}-\hat{e}_{t-1}\right)\right]+0.0026 \varepsilon_{m, t}
\end{aligned}
$$

where TZ refers to the target zone policy rule in the baseline estimation, IT to the inflation targeting rule in the baseline estimation, and $\mathrm{NRC}$ to the policy rule estimated in the NRC estimation.

We need to be careful in the comparison between the IT and NRC rules vs. the TZ when it comes to the exchange rate because we consider different measures of exchange rate movements in those rules. Not withstanding this caveat, we could expect that when we ignore the regime change in the estimation we would get stronger interest rate response to the rate of exchange rate devaluation than in the inflation targeting period alone - because it needs to account for the response in the target zone regime, which ought to be fairly strong in order to keep the regime credible. Indeed that is the case. However, the coefficient on the exchange rate depreciation is very small in both the inflation targeting regime and the NRC estimation, while there is a strong response to the exchange rate deviations from the central parity in the target zone regime. These parameter configurations indicate that ignoring the regime change would imply, ceteris paribus, a policy response to the exchange rate as much as 6 times larger than compared to the inflation targeting rule. For shocks that imply a strong response in the exchange rate this can be important.

It is worth mentioning that the response to output is negligible in both the IT period and the NRC estimation. However, in the TZ period there is a fairly strong response to output. This means that if we focus on the current policy response function there is no bias on this 


\section{Monetary Regime Change and Business Cycles}

coefficient if we omit the regime change in the estimation. The response to inflation is more or less comparable across periods and estimations.

It is also possible to observe that the volatility of the shocks to the policy rule is almost 4 times bigger in the target zone regime compared to the inflation targeting regime $(0.0058$ compared to 0.0015), suggesting that the policy is more predictable in the inflation targeting regime (also due to the bigger persistence of the interest rate). Ignoring the regime change in the estimation gives a volatility that is somewhat in-between (0.0026), which is not a total surprise - a similar result applies to the persistency of the interest rate level.

The characteristics of the risk premium shock are very different across regimes, much like the monetary policy shock, especially in terms of volatility. It is thus not surprising that the volatility in the NRC estimation is in between that of the two separate periods in the baseline estimation.

Turning to the parameters considered to be constant across regimes in both estimations (upper two blocks in Table 7), we find that both prices and wages have estimated degrees of rigidity that are similar across the two estimations $\left(\alpha_{p} \approx 0.85, \alpha_{w}=0.95\right)$. This element is important because nominal rigidities are key for the role of monetary policy and finding that they are not sensitive to the inclusion of the monetary regime break is an indication that the model is somewhat robust to the monetary regime specification, at least in this respect. However, when we compare the price-elasticity of foreign demand, $\eta$, across the two estimations, the posterior median is very different (1.76 in the benchmark estimation, compared to 2.56 in the $\mathrm{NRC}$ ), which suggests that exports are more sensitive to changes in relative prices in the NRC case. This is obviously important for the estimation of a small (very) open economy model, as is the case for Sweden.

Two other structural parameters that do not show robustness across estimation with and without regime change are the households' preference parameters. The intertemporal elasticity of substitution, $\sigma_{c}^{-1}$, is much higher in the NRC estimation compared to the benchmark 


\section{Monetary Regime Change and Business Cycles}

(3.68, compared to 1.06). The habit formation parameter, $v$, is also somewhat sensitive to the assumption of a regime change. In particular, it is very high (0.90) if we ignore regime change, but it is extremely high (0.97) if we acknowledge the regime change. This implies that the sensitivity of consumption to the interest rate, $(1-v) \sigma_{c}^{-1}$ is substantially higher in the NRC estimation than in the baseline estimation ( 0.36 versus 0.03 , so about one order of magnitude). It is true that nominal rigidities affect how much impact the monetary policy can have on the economy and they are stable across estimation assumptions, but the sensitivity of demand to the real interest rate is crucial for the evaluation of how the demand responds to monetary policy, and this is at the heart of the transmission mechanism. Our results show that the transmission mechanism is influenced by whether we acknowledge the regime shift in the estimation or not. In particular the results suggest that the policy rate has to move about ten times more when we acknowledge the regime change in order to achieve the same impact in household expenditure, compared to the assumption of no regime change.

The differences relate to the parameters of the preference shock. In the NRC estimation this shock is both less persistent and less volatile. In terms of volatility it is one order of magnitude smaller, much like the sensitivity of consumption to the real interest rate. From the Euler equation,

$$
E_{t} \hat{C}_{t+1}-(1+v) \hat{C}_{t}+v \hat{C}_{t-1}=\sigma_{c}^{-1}(1-v)\left(\hat{\imath}_{t}-E_{t} \hat{\pi}_{t+1}\right)+\sigma_{c}^{-1}(1-v)\left(E_{t} \hat{\xi}_{t+1}-\hat{\xi}_{t}\right)
$$

it is clear that if we interpret $\hat{\xi}_{t}$ as capturing shocks to consumption, its size is then influenced by the estimate for $\sigma_{c}^{-1}(1-v)$. Hence, if in the NRC we get $\sigma_{c}^{-1}(1-v)$ to be higher by a

factor of 10 , it is not surprising that the standard deviation of $\hat{\xi}_{t}$ is lower by a factor of 10 , which keeps the response of consumption to that shock roughly similar. Hence this change is not surprising once we establish the difference in the sensitivity of consumption to the real 


\section{Monetary Regime Change and Business Cycles}

interest rate.

Another parameter of interest for a small open economy is the degree of sensitivity of the interest rate to the level of debt, $\omega$. If we acknowledge the regime change this parameter is 0.10, while if we ignore the regime change we get a posterior median of 0.40 , which implies a much higher sensitivity of the country risk-premium to the net indebtedness of the country. This might be induced in the estimation by the need of the model to generate country risk premium during the target zone period that is no longer accounted for by the risk of realignment expectations. When we estimate the model taking into account the policy break, devaluation expectations appear to depend strongly on the current exchange rate deviation from the central parity. Because the NRC estimation does not account for that when generating the UIP relation it forces the risk premium to depend more strongly on the international indebtedness of the country.

The labor supply elasticity parameter, $\sigma_{l}$, and the investment adjustment cost, $\Phi$, are both smaller in the NRC case, compared to the benchmark, but neither of them by much. If we consider that habits and investment adjustment costs are two important channels of endogenous persistency then we conclude that ignoring the monetary policy regime change in the estimation leads to less endogenous persistency in terms of the real side of the economy. Regarding the parameters of the exogenous processes, they are mostly similar across the two estimations with the exception of the preferences shock, which was discussed previously.

The results discussed in this section are very important for two reasons. First, they show that an estimation of the policy rule that ignores the fact that there was a monetary policy regime change will result in a policy characterization that is not correct for either period. This is especially important if we want to use the estimation results to undertake forecasting

exercises. Second, ignoring the regime change in the estimation does affect the posterior distribution of the parameters that are supposed to be structural and independent of the policy regime, which will make the whole estimation unreliable. In particular this affects 


\section{Monetary Regime Change and Business Cycles}

the parameters associated with the demand side (the ones associated with the so-called "IS curve", which relates how the demand curve responds to the interest rate). If we want to conduct policy simulations based on such "structural" parameters then we may get biased simulations.

\subsection{Spurious Business Cycle Properties}

The omission of the monetary policy regime break and the biased estimation results documented in the previous subsection significantly affect the estimation of the dynamic

responses and sources of business cycle volatility. The results are shown in Figures 1 through 5 and Table 8.

The dynamic responses of output, inflation and employment after a productivity (fig. 4) or monetary shock (fig. 5) clearly illustrate this point. Even though the responses of these variables are similar during the IT and the TZ periods, the NRC estimation delivers very different results. After a technology shock, output and employment display more persistency while inflation decreases less on impact and it returns quicker to steady state in the NRC estimation than compared to the IT and TZ cases. Output, employment and inflation decrease much more substantially after a monetary shock in the NRC estimation than in the IT or TZ cases. Interestingly, in the NRC estimation both export and imports are more responsive after a monetary policy tightening.

The variance decomposition analysis also shows interesting results but mainly with respect to the secondary contributions to business cycle volatility. At the one-quarter-ahead horizon, the NRC estimation correctly identifies the biggest contribution to all the shocks, except for the real exchange rate. This is mainly because the persistent labor supply shocks play the biggest role in the three cases, IT, TZ and NRC. However, when it comes to the secondary contributions to business cycle volatility we find some more differences. For example the pref- 


\section{Monetary Regime Change and Business Cycles}

erence shock, $\xi_{t}$, has contributions of $8 \%$ and $21 \%$ in the TZ and IT regimes,respectively, while in the NRC estimation, not surprisingly, it settles in between, at $11 \%$. Moreover, the monetary policy shock has a residual contribution to the volatility of output in both the TZ and IT periods (1 and 5\%) but in the NRC regime it explains up to $14 \%$ of output fluctuations - clearly the misspecification of the policy regime induces a bias in the variance decomposition in the very short run.

At the 4-quarter-ahead horizon, we find similar results as for the 1-quarter-ahead case, in terms of the biggest contribution and the fact that the secondary contributions are biased in the NRC. For example, the productivity shock accounts for about $15 \%$ of the volatility of output in the two regimes but the $\mathrm{NRC}$ estimation assigns it $24 \%$. At the longer horizon (20 quarters ahead) the differences are more muted, but mainly because, as explained above, the labor supply shocks get most of the weight.

\section{Conclusion}

The main contribution of this paper is twofold: to show the implications of different monetary regimes on the macroeconomic dynamics of a small open economy and to quantify to what extent ignoring the regime shift in the estimation can produce spurious results.

We estimate a structural model for Sweden, a good example of a small open economy that went through a regime break. We explicitly account for the well documented monetary

policy regime shift that occurred after the speculative attack against the Swedish krona in 1992 and the consequent switch from a target zone regime to explicit inflation targeting. We then analyze the economy behavior across those two regimes and the main sources of volatility.

Consistent with common sense and a priori expectations, in the target zone regime, the Riksbank reacted strongly to exchange rate deviations from central parity, while under 


\section{Monetary Regime Change and Business Cycles}

inflation targeting, it reacted mainly to inflation. The two estimated monetary regimes have different effects on the transmission of different shocks and the difference is more clear after foreign shocks, which turn out to have a bigger impact on business cycles during the TZ period.

Applying the IT monetary policy rule to the shocks that hit the economy during the TZ period, would have led to higher output and employment but also to a depreciated currency, higher inflation and a more volatile economy.

Our main finding is that it is important to account for the regime change in the estimated DSGE to properly capture the information in the data. If we had estimated the model over the entire sample without accounting for this, we would have acquired business cycle properties that are averaged across the two periods and obtained spurious results for both the policy rule and the policy-independent parameters of the model.

It can be argued that, based on these results, we should attempt to develop a model that is more robust to the policy specification. However, it is not obvious ex-ante how one can do that in a systematic way without incurring the risk of simple data/model-mining. With

our paper we suggest that a first step is to make sure that the policy regime is properly characterized.

While it is usually a hard task to search for and identify policy regime breaks, in the Swedish case analyzed here this is not a problem. Both monetary policy regimes were well advertised, eliminating the need to search for a regime break, although the difficulty lies in incorporating this break explicitly in the estimation. Interestingly, a similar argument applies to a number of small open economies in which monetary and exchange rate regimes have been announced and changed during the last thirty years, thus compromising the estimation of models for these economies. 


\section{Monetary Regime Change and Business Cycles}

\section{References}

Adolfson, M., Laséen, S., Lindé, J., and Villani, M. (2007). Bayesian estimation of an open economy DSGE model with incomplete pass-through. Journal of International Economics, $72: 481-511$.

Adolfson, M., Laséen, S., Lindé, J., and Villani, M. (2008). Evaluating an estimated new keynesian small open economy model. Journal of Economic Dynamics and Control, $32(8): 2690-2721$.

Apel, M., Friberg, R., and Hallsten, K. (2005). Micro foundations of macroeconomic price adjustment: Survey evidence from swedish firms. Journal of Money, Credit and Banking, $37(2): 313-338$.

Benigno, P. (2001). Price stability with imperfect financial integration. Working Paper.

Betts, C. and Devereux, M. B. (2000). Exchange rate dynamics in a model of pricing to market. Journal of International Economics, 50(1):215-244.

Fernández-Villaverde, J. and Rubio-Ramírez (2007). How structural are structural parameters? In Daron Acemoglu, K. R. and Woodford, M., editors, NBER Macroeconomics Annual, volume 22, pages 83-137. MIT Press.

Friberg, K. and Wilander, F. (2007). Price setting transactions and the role of denominating currency in fx markets. Sveriges Riksbank Working Paper, 201.

Gelman, A., Carlin, J. B., Stern, H. S., and Rubin, D. B. (2004). Bayesian Data Analysis. Chapman and Hall/CRC, second edition.

Geweke, J. (1999). Using simulation methods for bayesian econometric models: Inference, development, and communication. Econometric Reviews, 18(1):1-73. 


\section{Monetary Regime Change and Business Cycles}

Gottfries, N. (2002). Market shares, financial constraints and pricing behavior in the export market. Economica, 69(276):583-607.

Heikensten, L. and Vredin, A. (1998). Inflation targeting and swedish monetary policyexperience and problems. Sveriges Riksbank Quarterly Review, 4:5-33.

Johansson, K. (1998). Exports in the econometric model KOSMOS. Swedish National Institute of Economic Research Working Paper Series, 62.

Justiniano, A. and Preston, B. (2010a). Can structural small open economy models account for the influence of foreign disturbances? Journal of International Economics (forthcoming).

Justiniano, A. and Preston, B. (2010b). Monetary policy and uncertainty in an empirical small open economy model. Journal of Applied Econometrics (forthcoming).

Justiniano, A. and Primiceri, G. E. (2008). The time varying volatility of macroeconomic fluctuations. The American Economic Review, 9(3):604-664.

Kollmann, R. (2001). The exchange rate in a dynamic-optimizing business cycle model with nominal rigidities: a quantitative investigation. Journal of International Economics, $55(2): 243-262$.

Lane, P. R. and Milesi-Ferretti, G. M. (2001). Long-term capital movements. International Monetary Fund Working Paper, 01-107.

Lindbeck, A., Molander, P., Persson, T., Petersson, O., Sandmo, A., Swedenborg, B., and Thygesen, N. (1994). Turning Sweden Around. The MIT Press.

Lindberg, H. and Soderlind, P. (1994). Testing the basic target zone model on swedish data 1982-1990. European Economic Review, 38(7):1441-69. 


\section{Monetary Regime Change and Business Cycles}

Lindberg, H., Söderlind, P., and Svensson, L. E. O. (1993). Devaluation expectations: The swedish krona 1985-92. Economic Journal, 103(420):1170-79.

Lindé, J. (2004). Swedish postwar business cycles: Generated abroad or at home? Scandinavian Journal of Economics, 106(4):623-645.

Lindé, J., Nessén, M., and Söderström, U. (2009). Monetary policy in an estimated open economy model with imperfect pass-through. International Journal of Finance and Economics, 14(4):301-333.

Lubik, T. and Schorfheide, F. (2007). Do central banks respond to exchange rate movements? a structural investigation. Journal of Monetary Economics, 54(4):1069-1087.

Martins, J. O., Scarpetta, S., and Pilat, D. (1996). Mark-up pricing, market structure and the business cycle. OECD Economic Studies, 27:71-105.

Smets, F. and Wouters, R. (2003). An estimated dynamic stochastic general equilibrium model of the Euro area. Journal of the European Economic Association, 1(5):1123-1175.

Svensson, L. E. O. (1994). Why exchange rate bands? monetary independence in spite of fixed exchange rates. Journal of Monetary Economics, 33(1):157-199.

Wilander, F. (2006). An empirical analysis of the currency denomination in international trade. Mimeo, Stockholm School of Economics.

Woodford, M. (2003). Interest and Prices. Princeton University Press, Princeton. 


\section{Monetary Regime Change and Business Cycles}

\section{A Log-linearized Equations}

In this section, we present all log-linearized expressions, using the notation of $\hat{X}_{t}=$ $\ln \left(X_{t} / X\right)$. The expressions for the final and intermediate goods sectors are given by:

$$
\begin{aligned}
& \hat{Z}_{t}=\alpha_{d} \hat{Q}_{t}^{d}+\left(1-\alpha_{d}\right) \hat{Q}_{t}^{m} \\
& \hat{Q}_{t}^{d}=\hat{Z}_{t}-\hat{P}_{t}^{d r} \\
& \hat{Q}_{t}^{m}=\hat{Z}_{t}-\hat{P}_{t}^{m r} \\
& \hat{Q}_{t}^{x}=\hat{Y}_{t}^{*}-\eta \hat{P}_{t}^{x r}, \\
& \hat{Y}_{t}=\frac{\alpha_{d}(1+\nu)}{\alpha_{d}(1+\nu)+\left(1-\alpha_{d}\right)} \hat{Q}_{t}^{d}+\frac{1-\alpha_{d}}{\alpha_{d}(1+\nu)+\left(1-\alpha_{d}\right)} \hat{Q}_{t}^{x}, \\
& \hat{Y}_{t}=\hat{\theta}_{t}+\hat{K}_{t}+(1-\psi)\left(\hat{R}_{t}^{r}-\hat{W}_{t}^{r}\right) \\
& \hat{L}_{t}=\hat{R}_{t}^{r}-\hat{W}_{t}^{r}+\hat{K}_{t} \\
& \hat{s}_{t}=-\hat{\theta}_{t}+\psi \hat{R}_{t}^{r}+(1-\psi) \hat{W}_{t}^{r}, \\
& 0=\alpha_{d} \hat{P}_{t}^{d r}+\left(1-\alpha_{d}\right) \hat{P}_{t}^{m r}, \\
& \left(1+\alpha_{p}^{2} \beta\right) \hat{P}_{t}^{x r}=\alpha_{p} \beta E_{t} \hat{\pi}_{t+1}^{*}-\alpha_{p} \hat{\pi}_{t}^{*}+\alpha_{p} \hat{P}_{t-1}^{x r}+\alpha_{p} \beta E_{t} \hat{P}_{t+1}^{x r}, \\
& +\left(1-\alpha_{p}\right)\left(1-\alpha_{p} \beta\right)\left[\hat{s}_{t}-\hat{q}_{t}\right]+\alpha_{p} \hat{\nu}_{t} \\
& \left(1+\alpha_{p}^{2} \beta\right) \hat{P}_{t}^{m r}=\alpha_{p} \beta E_{t} \hat{\pi}_{t+1}-\alpha_{p} \hat{\pi}_{t}+\alpha_{p} \hat{P}_{t-1}^{m r}+\alpha_{p} \beta E_{t} \hat{P}_{t+1}^{m r} \\
& +\left(1-\alpha_{p}\right)\left(1-\alpha_{p} \beta\right) \hat{q}_{t}+\alpha_{p} \hat{\nu}_{t}
\end{aligned}
$$


Monetary Regime Change and Business Cycles

$$
\hat{\pi}_{t}=\beta E_{t} \hat{\pi}_{t+1}+\frac{\left(1-\alpha_{p}\right)\left(1-\alpha_{p} \beta\right)}{\alpha_{p}}\left[\alpha_{d} \hat{s}_{t}+\left(1-\alpha_{d}\right) \hat{q}_{t}\right]+\hat{\nu}_{t} .
$$

The household first-order conditions are:

$$
\begin{aligned}
& 0=\hat{\imath}_{t}+E_{t} \hat{\xi}_{t+1}-\hat{\xi}_{t}-E_{t} \hat{\pi}_{t+1}-\frac{\sigma_{c}}{1-v}\left[E_{t} \hat{C}_{t+1}-(1+v) \hat{C}_{t}+v \hat{C}_{t-1}\right] \\
& \hat{\imath}_{t}=E_{t} \hat{\pi}_{t+1}+[1-\beta(1-\delta)] E_{t} \hat{R}_{t+1}^{r}+\Phi \beta E_{t} \hat{K}_{t+2}-\Phi(1+\beta) \hat{K}_{t+1}+\Phi \hat{K}_{t}, \\
& (1+\beta) \hat{W}_{t}^{r}=\hat{W}_{t-1}^{r}+\beta E_{t} \hat{W}_{t+1}^{r}-\hat{\pi}_{t}+\beta E_{t} \hat{\pi}_{t+1} \\
& +\frac{\left(1-\alpha_{w}\right)\left(1-\alpha_{w} \beta\right)}{\left(1+\frac{1+\gamma}{\gamma} \sigma_{l}\right) \alpha_{w}}\left[\frac{\sigma_{c}}{1-v}\left(\hat{C}_{t}-v \hat{C}_{t-1}\right)+\sigma_{l} \hat{L}_{t}-\hat{W}_{t}^{r}\right]+\hat{\gamma}_{t}+\hat{\kappa}_{t} .
\end{aligned}
$$

The balance of payment is:

$$
\hat{B}_{t}=\beta^{-1} \hat{B}_{t-1}+\hat{P}_{t}^{x r}+\hat{Q}_{t}^{x}-\hat{Q}_{t}^{m}
$$

Equilibrium in the goods market requires:

$$
\hat{Z}_{t}=\left(1-\delta \frac{K}{Z}\right) \hat{C}_{t}+\frac{K}{Z}\left[\hat{K}_{t+1}-(1-\delta) \hat{K}_{t}\right]
$$

The foreign sector is assumed to follow an exogenous VAR:

$$
G_{0}\left[\begin{array}{c}
\hat{Y}_{t}^{*} \\
\hat{\pi}_{t}^{*} \\
\hat{\imath}_{t}^{*}
\end{array}\right]=G_{1}\left[\begin{array}{c}
\hat{Y}_{t-1}^{*} \\
\hat{\pi}_{t-1}^{*} \\
\hat{\imath}_{t-1}^{*}
\end{array}\right]+\left[\begin{array}{c}
\varepsilon_{y}^{*} \\
\varepsilon_{p}^{*} \\
\varepsilon_{i}^{*}
\end{array}\right]
$$




\section{Monetary Regime Change and Business Cycles}

The monetary policy rule during the target zone is:

$$
\hat{\imath}_{t}=\rho_{m, T Z} \hat{\imath}_{t-1}+\left(1-\rho_{m, T Z}\right)\left[\Gamma_{p, T Z} \hat{\pi}_{t}+\Gamma_{y, T Z} \hat{Y}_{t} / 4+\Gamma_{e, T Z} \hat{e}_{t}\right]+\varepsilon_{m_{T Z}, t},
$$

while the uncovered interest parity condition takes the following expression:

$$
\hat{\imath}_{t}=\hat{\imath}_{t}^{*}+E_{t} \hat{e}_{t+1}+\left(\rho_{x}-1\right) \hat{e}_{t}-\omega \hat{B}_{t}+\zeta_{t, T Z}
$$

The monetary policy rule during the inflation targeting period is:

$$
\hat{\imath}_{t}=\rho_{m, I T} \hat{\imath}_{t-1}+\left(1-\rho_{m, I T}\right)\left[\Gamma_{p, I T} \hat{\pi}_{t}+\Gamma_{y, I T} \hat{Y}_{t} / 4+\Gamma_{e, I T} \Delta \hat{e}_{t}\right]+\varepsilon_{m_{I T}, t},
$$

while the uncovered interest parity condition takes the following expression:

$$
\hat{\imath}_{t}=\hat{\imath}_{t}^{*}+E_{t} \hat{e}_{t+1}-\hat{e}_{t}-\omega \hat{B}_{t}+\zeta_{t, I T} \text {. }
$$




\section{Monetary Regime Change and Business Cycles}

\section{B Data}

Tables 1 and 2 report data sources and mnemonic codes. All data series are logged and detrended by a linear trend. An exception is the interest rate, for which the gaps were defined as in the text, i.e., as the difference between the level and the trend divided by the gross interest rate value of the trend.

For the exchange rate, we take into account that there are two regimes and the trend is therefore different. During a credible target zone, the trend should simply be a constant, except for revaluations and devaluations. The target zone period subsample goes from 1980:1 to 1992:3. During that period the Swedish krona experiences two devaluations: in September 1981 and October 1982. After these devaluations and until 1992, the exchange rate was more or less constant and there was no clear trend of departure from central parity. We take central parity as the trend for this period. Therefore, we treat the deviations from central parity as an observable. The reason for this treatment of the exchange rate in the target zone period is that we do not want to explicitly model the determinants of devaluations, so we consider the central parity variable to always be constant, despite the two devaluations actually observed. In the second quarter of 1991, central parity switched to the ECU composite currency instead of the previous basket. This regime only lasted until the end of 1992. Since this is such a short time period and still a target zone regime, we simplify by assuming that the previous regime was still in place. For the free floating period, we compute a simple linear trend.

The exchange rate is defined as the number of Swedish kronor per foreign currency. The trade weights were obtained from two different sources. For the first part of the sample, we have exact weights provided in Lindberg and Soderlind (1994) and for the second part we took the weights from the Swedish National Institute of Economic Research.

We use CPI to construct inflation series and the GDP deflator to convert nominal GDP into real. 


\section{Tables and Figures}

Table 1: Data for Sweden.

\begin{tabular}{lll}
\hline \hline Variable & Description & Source/Code \\
\hline Interest Rate & Repo & ifs:s14460a00zfq \\
Exchange Rate & Spot rate & ew:swe19001 \\
CPI & Urban and Rural Areas & ifs:s14464000zfq \\
Nominal GDP & - & ifs:s14499b00zfq \\
GDP deflator & Base year 2000 & ifs:s14499bipzfq \\
Consumption & Household Consumption Expenditure & ifs:s14496f00zfq \\
Population & Population 16-64 years & Riksbank \\
Wages & Hourly wage, whole economy & Riksbank \\
Labour & Hours worked, whole economy & Riksbank \\
& holiday corrected & \\
\hline \hline
\end{tabular}

*Sources: ew: Ecowin, ifs: International Financial Statistics 
Table 2: Data for the Foreign Sector.

\begin{tabular}{|c|c|c|c|c|c|}
\hline & Interest Rate & $\begin{array}{c}\text { Exchange Rate } \\
\text { USD/\# }\end{array}$ & CPI & Nominal GDP & GDP deflator \\
\hline \multirow[t]{3}{*}{ FR } & EW & EW & IFS & EW & IFS \\
\hline & fra14203 & fra19001 & s13264000zfq & fra01023 & s13299birzfq \\
\hline & Euribor 3 Month & & 108 Cities & & \\
\hline \multirow[t]{3}{*}{$\mathrm{DE}$} & IFS & EW & EW & IFS & IFS \\
\hline & s13460c00zfq & deu19001 & deu11071 & s13499b0czfq & s13499birzfq \\
\hline & Treasury Bill Rate & & All items, Total & & \\
\hline \multirow[t]{3}{*}{ IT } & IFS & EW & IFS & IFS & IFS \\
\hline & s13660c00zfq & ita19001 & s13664000zfq & s13699b0czfq & s13699birzfq \\
\hline & Treasury Bill Rate & & All Italy & & \\
\hline \multirow[t]{4}{*}{ NL } & EW & EW & IFS & IFS & IFS \\
\hline & nld14205 & nld19001 & s13864000zfq & s13899b0czfq & s13899birzfq \\
\hline & Euribor $3 \mathrm{~m}$ & & Wage earners & & \\
\hline & & & median income & & \\
\hline \multirow[t]{3}{*}{ UK } & IFS & EW & IFS & IFS & IFS \\
\hline & s11260 & gbr19001 & s11264000zfq & s11299b0czfq & s11299birzfq \\
\hline & Treasury Bill Rate & & All items & & \\
\hline \multirow[t]{3}{*}{ US } & IFS & & IFS & EW & IFS \\
\hline & s11160c00zfq & - & s11164000zfq & usa01151 & s11199birzfq \\
\hline & Treasury Bill Rate & & $\begin{array}{l}\text { All items } \\
\text { citv average }\end{array}$ & & \\
\hline \multirow[t]{3}{*}{ FI } & IFS & EW & IFS & IFS & IFS \\
\hline & s17260b00zfq & fin19001 & s17264000zfq & s17299b00zfq & s17299bipzfq \\
\hline & Average Cost & & All country & & \\
\hline \multirow[t]{3}{*}{ JP } & IFS & EW & IFS & EW & IFS \\
\hline & s15860b00zfq & jpn19001 & s15864000zfq & jpn01320 & s15899birzfq \\
\hline & Call Money Rate & & All Japan, 485 items & & \\
\hline \multirow{4}{*}{ NO } & IFS & EW & IFS & IFS & IFS \\
\hline & s14260b00zfq & nor19001 & s14264000zfq & s14299b00zfq & s14299bipzfq \\
\hline & Call Money Rate & & National & & \\
\hline & & & all consumers & & \\
\hline \multirow[t]{3}{*}{ DK } & EW & EW & IFS & IFS & IFS \\
\hline & dnk14010 & dnk19001 & s12864000zfq & s12899b00zfq & s12899bipzfq \\
\hline & Treasury Bills, 3m & & 70 localities & & \\
\hline EU & & $\begin{array}{c}\text { EW } \\
\text { emu19001 }\end{array}$ & & & \\
\hline
\end{tabular}

*Source: EW: Ecowin, IFS: International Financial Statistics 
Monetary Regime Change and Business Cycles

Table 3: Parameter posteriors in the baseline estimation.

\begin{tabular}{|c|c|c|c|c|c|c|c|}
\hline & \multicolumn{4}{|c|}{ Prior } & \multicolumn{3}{|c|}{ Posterior } \\
\hline & Dist. & $5 \%$ & Median & $95 \%$ & $5 \%$ & Median & $95 \%$ \\
\hline$\eta$ & IG2 & 1.0810 & 1.4625 & 2.0464 & 1.5244 & 1.7581 & 2.0273 \\
\hline$\alpha_{p}$ & B & 0.5834 & 0.7752 & 0.9098 & 0.8295 & 0.8525 & 0.8741 \\
\hline$\alpha_{w}$ & B & 0.5834 & 0.7752 & 0.9098 & 0.9340 & 0.9526 & 0.9679 \\
\hline$\sigma_{c}$ & G & 0.6832 & 1.8360 & 3.8768 & 0.2710 & 0.9403 & 2.4572 \\
\hline$\sigma_{l}$ & G & 0.3416 & 0.9180 & 1.9384 & 0.3028 & 0.8566 & 1.9333 \\
\hline$\Phi$ & G & 3.4158 & 9.1802 & 19.3841 & 13.9005 & 18.2860 & 23.9798 \\
\hline$v$ & B & 0.5242 & 0.7068 & 0.8525 & 0.9482 & 0.9704 & 0.9852 \\
\hline$\omega$ & G & 0.2035 & 0.3409 & 0.5296 & 0.0608 & 0.1033 & 0.1677 \\
\hline$\rho_{\xi}$ & B & 0.4472 & 0.7448 & 0.9347 & 0.2196 & 0.3518 & 0.4873 \\
\hline$\hat{\rho_{\theta}}$ & B & 0.4472 & 0.7448 & 0.9347 & 0.9881 & 0.9956 & 0.9990 \\
\hline$\rho_{\kappa}$ & $\mathrm{B}$ & 0.4472 & 0.7448 & 0.9347 & 0.9913 & 0.9971 & 0.9994 \\
\hline$\sigma_{\xi}$ & IG2 & 0.2108 & 0.5958 & 2.8140 & 1.2056 & 4.5642 & 13.4345 \\
\hline$\sigma_{\theta}$ & IG2 & 0.2108 & 0.5958 & 2.8140 & 1.2181 & 1.3537 & 1.5153 \\
\hline$\sigma_{\kappa}$ & IG2 & 0.2108 & 0.5958 & 2.8140 & 0.0666 & 0.0972 & 0.1464 \\
\hline$\sigma_{\nu}$ & IG2 & 0.2108 & 0.5958 & 2.8140 & 0.6662 & 0.7470 & 0.8435 \\
\hline$\sigma_{\gamma}$ & IG2 & 0.2108 & 0.5958 & 2.8140 & 0.7790 & 0.8785 & 1.0003 \\
\hline$\Gamma_{p, T Z}$ & G & 1.6099 & 1.9928 & 2.4321 & 1.4400 & 1.7776 & 2.1554 \\
\hline$\Gamma_{y, T Z}$ & $\mathrm{G}$ & 0.1708 & 0.4590 & 0.9692 & 0.4372 & 0.6644 & 1.0036 \\
\hline$\Gamma_{e, T Z}$ & $\mathrm{TN}$ & 0.1254 & 1.3490 & 3.9199 & 0.8259 & 1.2980 & 2.0286 \\
\hline$\rho_{m, T Z}$ & B & 0.7126 & 0.8032 & 0.8765 & 0.7673 & 0.8240 & 0.8714 \\
\hline$\sigma_{m, T Z}$ & IG2 & 0.2108 & 0.5958 & 2.8140 & 0.4447 & 0.5815 & 0.8050 \\
\hline$\rho_{x}$ & $\mathrm{G}$ & 0.1036 & 0.2278 & 0.4259 & 0.2620 & 0.3570 & 0.4796 \\
\hline$\rho_{\zeta, T Z}$ & B & 0.4472 & 0.7448 & 0.9347 & 0.4715 & 0.6346 & 0.7774 \\
\hline$\sigma_{\zeta, T Z}$ & IG2 & 0.2108 & 0.5958 & 2.8140 & 0.3673 & 0.4967 & 0.6765 \\
\hline$\Gamma_{p, I T}$ & G & 1.6099 & 1.9928 & 2.4321 & 1.7271 & 2.0627 & 2.4650 \\
\hline$\Gamma_{y, I T}$ & $\mathrm{G}$ & 0.1708 & 0.4590 & 0.9692 & 0.0042 & 0.0117 & 0.0268 \\
\hline$\Gamma_{e, I T}$ & $\mathrm{TN}$ & 0.1254 & 1.3490 & 3.9199 & 0.0014 & 0.0181 & 0.0703 \\
\hline$\rho_{m, I T}$ & B & 0.7126 & 0.8032 & 0.8765 & 0.8752 & 0.9007 & 0.9219 \\
\hline$\sigma_{m, I T}$ & IG2 & 0.2108 & 0.5958 & 2.8140 & 0.1298 & 0.1526 & 0.1847 \\
\hline$\rho_{\zeta, I T}$ & B & 0.4472 & 0.7448 & 0.9347 & 0.5998 & 0.7062 & 0.7922 \\
\hline$\sigma_{\zeta, I T}$ & IG2 & 0.2108 & 0.5958 & 2.8140 & 0.9983 & 1.4379 & 2.0877 \\
\hline
\end{tabular}

* For the IG2 distribution(s), shape parameter is shown instead of SE. 
Table 4: Variance decomposition for the target zone period in the baseline estimation.

\begin{tabular}{|c|c|c|c|c|c|c|c|c|}
\hline & Pref. & Tech. & Mon. & $\begin{array}{c}\text { Foreign } \\
\text { Shocks }\end{array}$ & $\begin{array}{l}\text { Labor } \\
\text { Supply }\end{array}$ & $\begin{array}{c}\text { Price } \\
\text { Markup }\end{array}$ & $\begin{array}{c}\text { Wage } \\
\text { Markup }\end{array}$ & $\begin{array}{c}\text { Risk } \\
\text { Premium }\end{array}$ \\
\hline \multicolumn{9}{|c|}{1 quarter } \\
\hline$Y$ & 0.0820 & 0.1250 & 0.0050 & 0.0591 & 0.6227 & 0.0759 & 0.0165 & 0.0065 \\
\hline$\pi$ & 0.0001 & 0.0263 & 0.0003 & 0.0009 & 0.0138 & 0.3703 & 0.5865 & 0.0000 \\
\hline$i$ & 0.0147 & 0.0038 & 0.5730 & 0.0475 & 0.0995 & 0.0095 & 0.0002 & 0.2343 \\
\hline$e$ & 0.0879 & 0.0551 & 0.0054 & 0.0640 & 0.6702 & 0.0823 & 0.0178 & 0.0071 \\
\hline$q$ & 0.0154 & 0.0010 & 0.4770 & 0.0282 & 0.0659 & 0.1974 & 0.0004 & 0.1988 \\
\hline \multicolumn{9}{|c|}{4 quarters } \\
\hline$Y$ & 0.0718 & 0.1662 & 0.0014 & 0.0516 & 0.6438 & 0.0312 & 0.0234 & 0.0026 \\
\hline$\pi$ & 0.0023 & 0.1518 & 0.0004 & 0.0063 & 0.0900 & 0.2607 & 0.4837 & 0.0000 \\
\hline$i$ & 0.0221 & 0.0190 & 0.4801 & 0.0662 & 0.1996 & 0.0133 & 0.0021 & 0.1771 \\
\hline$e$ & 0.0977 & 0.0168 & 0.0017 & 0.0613 & 0.7446 & 0.0389 & 0.0282 & 0.0030 \\
\hline$q$ & 0.0294 & 0.0317 & 0.3789 & 0.0834 & 0.0737 & 0.2258 & 0.0076 & 0.1437 \\
\hline \multicolumn{9}{|c|}{20 quarters } \\
\hline$Y$ & 0.0075 & 0.1443 & 0.0001 & 0.0219 & 0.8023 & 0.0028 & 0.0186 & 0.0002 \\
\hline$\pi$ & 0.0110 & 0.4505 & 0.0001 & 0.0099 & 0.3803 & 0.0386 & 0.0973 & 0.0000 \\
\hline$i$ & 0.0077 & 0.1278 & 0.1266 & 0.0481 & 0.6063 & 0.0073 & 0.0171 & 0.0465 \\
\hline$e$ & 0.0155 & 0.0126 & 0.0002 & 0.0252 & 0.9147 & 0.0040 & 0.0226 & 0.0003 \\
\hline$q$ & 0.0153 & 0.2233 & 0.1094 & 0.1292 & 0.3452 & 0.0771 & 0.0383 & 0.0417 \\
\hline
\end{tabular}


Table 5: Variance decomposition for the inflation targeting period in the baseline estimation.

\begin{tabular}{ccccccccc}
\hline \hline \multicolumn{2}{c}{ Pref. } & Tech. & Mon. & $\begin{array}{c}\text { Foreign } \\
\text { Shocks }\end{array}$ & $\begin{array}{c}\text { Labor } \\
\text { Supply }\end{array}$ & $\begin{array}{c}\text { Price } \\
\text { Markup }\end{array}$ & $\begin{array}{c}\text { Wage } \\
\text { Markup }\end{array}$ & $\begin{array}{c}\text { Risk } \\
\text { Premium }\end{array}$ \\
\hline \multicolumn{1}{l}{ quarter } & & & & & & & \\
\hline$Y$ & 0.2049 & 0.1017 & 0.0511 & 0.0162 & 0.4880 & 0.1065 & 0.0134 & 0.0089 \\
$\pi$ & 0.0011 & 0.0100 & 0.0023 & 0.0018 & 0.0814 & 0.3365 & 0.5546 & 0.0080 \\
$i$ & 0.0017 & 0.0278 & 0.0524 & 0.0389 & 0.1748 & 0.0013 & 0.0034 & 0.6926 \\
$e$ & 0.1880 & 0.1734 & 0.0467 & 0.0147 & 0.4476 & 0.0972 & 0.0123 & 0.0081 \\
$q$ & 0.0009 & 0.0357 & 0.0493 & 0.0297 & 0.1602 & 0.0239 & 0.0048 & 0.6875 \\
\hline 4 quarters & & & & & & & \\
\hline$Y$ & 0.1497 & 0.1518 & 0.033 & 0.0108 & 0.5858 & 0.0307 & 0.0211 & 0.0107 \\
$\pi$ & 0.0071 & 0.0409 & 0.0075 & 0.0067 & 0.3849 & 0.1750 & 0.3533 & 0.0171 \\
$i$ & 0.0035 & 0.0418 & 0.0635 & 0.0575 & 0.3028 & 0.0008 & 0.0049 & 0.5157 \\
$e$ & 0.1786 & 0.0477 & 0.0352 & 0.0131 & 0.6418 & 0.0347 & 0.0239 & 0.0132 \\
$q$ & 0.0009 & 0.0733 & 0.0571 & 0.0357 & 0.2594 & 0.021 & 0.0104 & 0.5306 \\
\hline 20 & quarters & & & & & & & \\
\hline$Y$ & 0.0242 & 0.1046 & 0.0079 & 0.0029 & 0.8416 & 0.0018 & 0.0127 & 0.0014 \\
$\pi$ & 0.0137 & 0.0695 & 0.0034 & 0.0051 & 0.8440 & 0.0152 & 0.0429 & 0.0028 \\
$i$ & 0.0237 & 0.0229 & 0.0356 & 0.0692 & 0.6829 & 0.0038 & 0.0028 & 0.1494 \\
$e$ & 0.0341 & 0.007 & 0.0076 & 0.0041 & 0.9245 & 0.0024 & 0.0137 & 0.0020 \\
$q$ & 0.0024 & 0.1075 & 0.0302 & 0.0230 & 0.6210 & 0.0077 & 0.0139 & 0.1889 \\
\hline \hline
\end{tabular}




\section{Monetary Regime Change and Business Cycles}

Table 6: Moments for some variables during the target zone period under the estimated policy for that period's policy regime (TZ Policy) and under the counterfactual experiment in which the estimated policy for the inflation targeting regime is used to respond to the shocks (IT Policy): mean and standard deviation.

\begin{tabular}{lrrrrrrr}
\hline \hline & \multicolumn{3}{c}{ Mean } & & \multicolumn{3}{c}{ Std. Dev. } \\
\cline { 2 - 5 } \cline { 7 - 8 } & TZ Policy & IT Policy & Difference & & TZ Policy & IT Policy & Difference \\
\hline Output & -3.602 & 14.176 & 17.779 & & 3.836 & 4.529 & 0.692 \\
Employment & -3.915 & 15.358 & 19.274 & & 1.693 & 6.789 & 5.096 \\
Capital stock & 19.002 & 33.714 & 14.712 & & 19.530 & 11.271 & -8.259 \\
Consumption & -2.302 & 7.920 & 10.222 & & 3.408 & 5.010 & 1.602 \\
Inflation & 0.052 & 0.448 & 0.396 & & 0.864 & 1.039 & 0.175 \\
Nom. interest rate & 0.531 & -0.677 & -1.207 & & 0.475 & 0.695 & 0.219 \\
Nom. exchange rate & 1.540 & 23.889 & 22.349 & & 0.646 & 10.321 & 9.675 \\
Real exchange rate & 1.388 & 14.566 & 13.178 & & 3.563 & 4.110 & 0.547 \\
Real wage rate & 1.772 & -2.013 & -3.785 & & 4.634 & 6.441 & 1.808 \\
\hline \hline
\end{tabular}




\section{Monetary Regime Change and Business Cycles}

Table 7: Parameter posteriors for the estimation without regime change (NRC), compared to the baseline estimation that incorporates the regime change.

\begin{tabular}{ccccccc}
\hline \hline & \multicolumn{5}{c}{ Regime Change (Baseline) } & \multicolumn{3}{c}{ No Regime Change (NRC) } \\
\cline { 2 - 7 } & $5 \%$ & Median & $95 \%$ & $5 \%$ & Median & $95 \%$ \\
\hline & & & & & & \\
$\eta$ & 1.5244 & 1.7581 & 2.0273 & 2.1953 & 2.5552 & 2.9758 \\
$\alpha_{p}$ & 0.8295 & 0.8525 & 0.8741 & 0.8245 & 0.8437 & 0.8622 \\
$\alpha_{w}$ & 0.9340 & 0.9526 & 0.9679 & 0.9281 & 0.9490 & 0.9660 \\
$\sigma_{c}$ & 0.2710 & 0.9403 & 2.4572 & 0.1905 & 0.2720 & 0.3887 \\
$\sigma_{l}$ & 0.3028 & 0.8566 & 1.9333 & 0.2147 & 0.6533 & 1.5449 \\
$\Phi$ & 13.9005 & 18.2860 & 23.9798 & 11.6927 & 15.4766 & 21.0604 \\
$v$ & 0.9482 & 0.9704 & 0.9852 & 0.8617 & 0.9029 & 0.9364 \\
$\omega$ & 0.0608 & 0.1033 & 0.1677 & 0.2564 & 0.3979 & 0.5868 \\
& & & & & & \\
$\rho_{\xi}$ & 0.2196 & 0.3518 & 0.4873 & 0.1417 & 0.2480 & 0.3761 \\
$\rho_{\theta}$ & 0.9881 & 0.9956 & 0.9990 & 0.9906 & 0.9966 & 0.9992 \\
$\rho_{\kappa}$ & 0.9913 & 0.9971 & 0.9994 & 0.9908 & 0.9969 & 0.9993 \\
$\sigma_{\xi}$ & 1.2056 & 4.5642 & 13.4345 & 0.2666 & 0.3803 & 0.6126 \\
$\sigma_{\theta}$ & 1.2181 & 1.3537 & 1.5153 & 1.2195 & 1.3536 & 1.5147 \\
$\sigma_{\kappa}$ & 0.0666 & 0.0972 & 0.1464 & 0.0597 & 0.0855 & 0.1247 \\
$\sigma_{\nu}$ & 0.6662 & 0.7470 & 0.8435 & 0.5549 & 0.6224 & 0.7057 \\
$\sigma_{\gamma}$ & 0.7790 & 0.8785 & 1.0003 & 0.7577 & 0.8532 & 0.9665 \\
$\Gamma_{p, T Z}$ & 1.4400 & 1.7776 & 2.1554 & - & & - \\
$\Gamma_{y, T Z}$ & 0.4372 & 0.6644 & 1.0036 & - & - & - \\
$\Gamma_{e, T Z}$ & 0.8259 & 1.2980 & 2.0286 & - & - & - \\
$\rho_{m, T Z}$ & 0.7673 & 0.8240 & 0.8714 & - & - & - \\
$\sigma_{m, T Z}$ & 0.4447 & 0.5815 & 0.8050 & - & - & - \\
$\rho_{x}$ & 0.2620 & 0.3570 & 0.4796 & - & - & - \\
$\rho_{\zeta, T Z}$ & 0.4715 & 0.6346 & 0.7774 & - & - & - \\
$\sigma_{\zeta, T Z}$ & 0.3673 & 0.4967 & 0.6765 & - & - & - \\
$\Gamma_{\zeta, I T}$ & 1.7271 & 2.0627 & 2.4650 & 1.4412 & 1.7035 & 2.0316 \\
$\Gamma_{\zeta, I T}$ & 0.0042 & 0.0117 & 0.0268 & 0.0023 & 0.0064 & 0.0143 \\
$\Gamma_{e, I T}$ & 0.0014 & 0.0181 & 0.0703 & 0.0168 & 0.1016 & 0.2279 \\
$\rho_{m, I T}$ & 0.8752 & 0.9007 & 0.9219 & 0.8108 & 0.8456 & 0.8758 \\
\hline \hline & 0.1298 & 0.1526 & 0.1847 & 0.2320 & 0.2639 & 0.3038 \\
$\sigma_{m, I T}$ & 0.5998 & 0.7062 & 0.7922 & 0.6334 & 0.7109 & 0.7799 \\
& 0.9983 & 1.4379 & 2.0877 & 0.8053 & 1.0525 & 1.3783 \\
\hline & & & & & &
\end{tabular}


Table 8: Variance decomposition for the estimation without regime change.

\begin{tabular}{|c|c|c|c|c|c|c|c|c|}
\hline & Pref. & Tech. & Mon. & $\begin{array}{c}\text { Foreign } \\
\text { Shocks }\end{array}$ & $\begin{array}{l}\text { Labor } \\
\text { Supply }\end{array}$ & $\begin{array}{c}\text { Price } \\
\text { Markup }\end{array}$ & $\begin{array}{c}\text { Wage } \\
\text { Markup }\end{array}$ & $\begin{array}{c}\text { Risk } \\
\text { Premium }\end{array}$ \\
\hline \multicolumn{9}{|c|}{1 quarter } \\
\hline$Y$ & 0.1096 & 0.1600 & 0.1361 & 0.0125 & 0.4449 & 0.1059 & 0.0179 & 0.0041 \\
\hline$\pi$ & 0.0015 & 0.0083 & 0.0087 & 0.0010 & 0.0848 & 0.2667 & 0.6201 & 0.0056 \\
\hline$i$ & 0.0046 & 0.0368 & 0.1688 & 0.0403 & 0.1531 & 0.0017 & 0.0036 & 0.5838 \\
\hline$e$ & 0.1262 & 0.0397 & 0.1566 & 0.0143 & 0.5094 & 0.1207 & 0.0203 & 0.0048 \\
\hline$q$ & 0.0034 & 0.0469 & 0.1563 & 0.0279 & 0.1338 & 0.0287 & 0.0053 & 0.5894 \\
\hline \multicolumn{9}{|c|}{4 quarters } \\
\hline$Y$ & 0.0568 & 0.2409 & 0.1083 & 0.0082 & 0.5068 & 0.0364 & 0.0292 & 0.0055 \\
\hline$\pi$ & 0.0056 & 0.0303 & 0.0291 & 0.0035 & 0.3906 & 0.1300 & 0.3941 & 0.0111 \\
\hline$i$ & 0.0082 & 0.0532 & 0.1882 & 0.0576 & 0.2706 & 0.0011 & 0.0048 & 0.4064 \\
\hline$e$ & 0.0795 & 0.0221 & 0.1410 & 0.0114 & 0.6439 & 0.0490 & 0.0386 & 0.0077 \\
\hline$q$ & 0.0047 & 0.0920 & 0.1668 & 0.0304 & 0.2147 & 0.0224 & 0.0110 & 0.4456 \\
\hline \multicolumn{9}{|c|}{20 quarters } \\
\hline$Y$ & 0.0050 & 0.1873 & 0.0251 & 0.0016 & 0.7577 & 0.0024 & 0.0183 & 0.0009 \\
\hline$\pi$ & 0.0040 & 0.0447 & 0.0171 & 0.0018 & 0.8614 & 0.0108 & 0.0545 & 0.0016 \\
\hline$i$ & 0.0135 & 0.0338 & 0.1056 & 0.0671 & 0.6717 & 0.0030 & 0.0020 & 0.0971 \\
\hline$e$ & 0.0076 & 0.0534 & 0.0305 & 0.0022 & 0.8752 & 0.0033 & 0.0226 & 0.0013 \\
\hline$q$ & 0.0055 & 0.1368 & 0.0826 & 0.0155 & 0.5749 & 0.0079 & 0.0136 & 0.1571 \\
\hline
\end{tabular}


Figure 1: Responses to a foreign interest shock. Solid line: TZ. Dashed line: IT. Dotted line: NRC
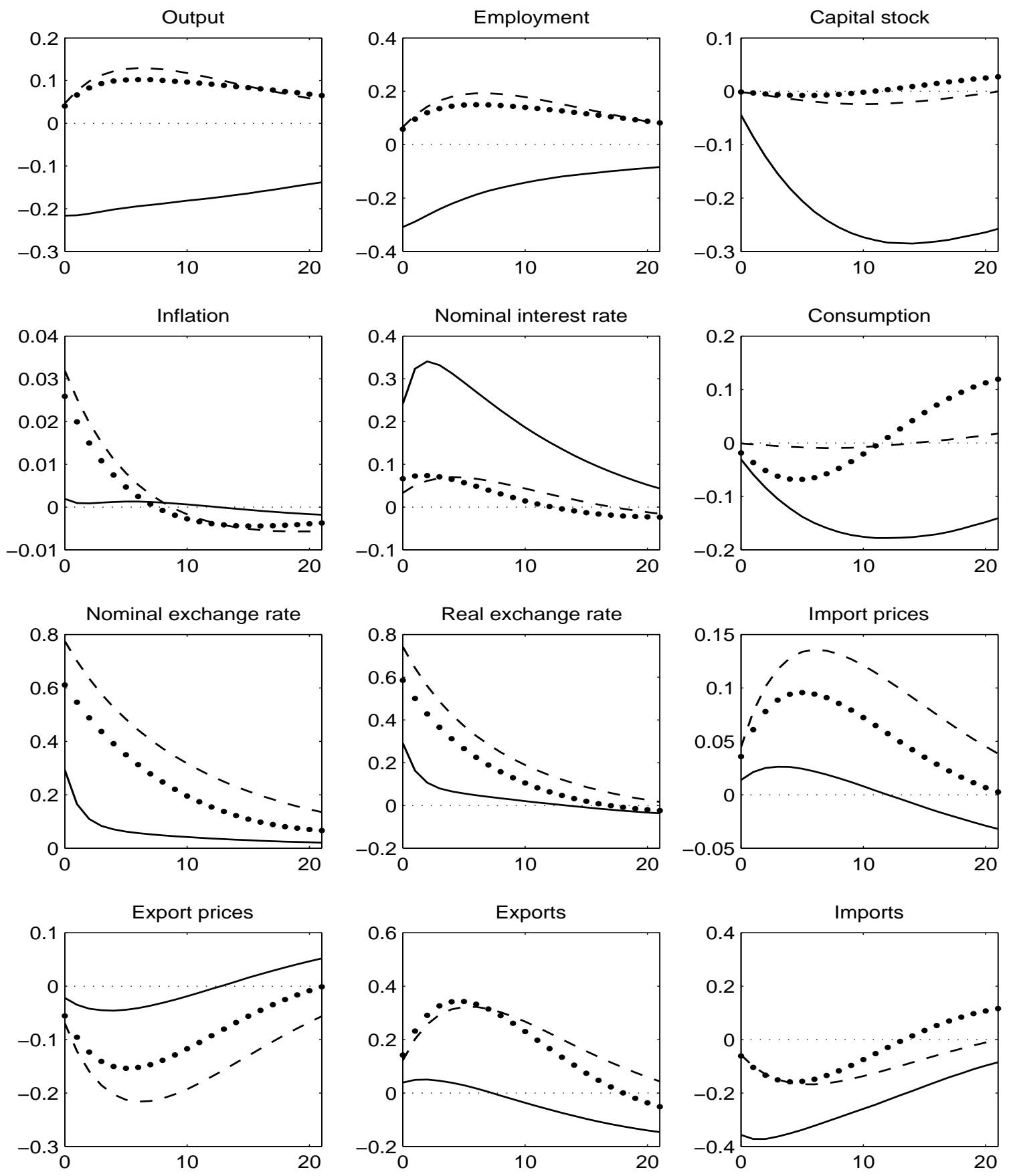
Figure 2: Responses to a realignment expectation and a risk premium shock. Solid line: TZ. Dashed line: IT. Dotted line: NRC.
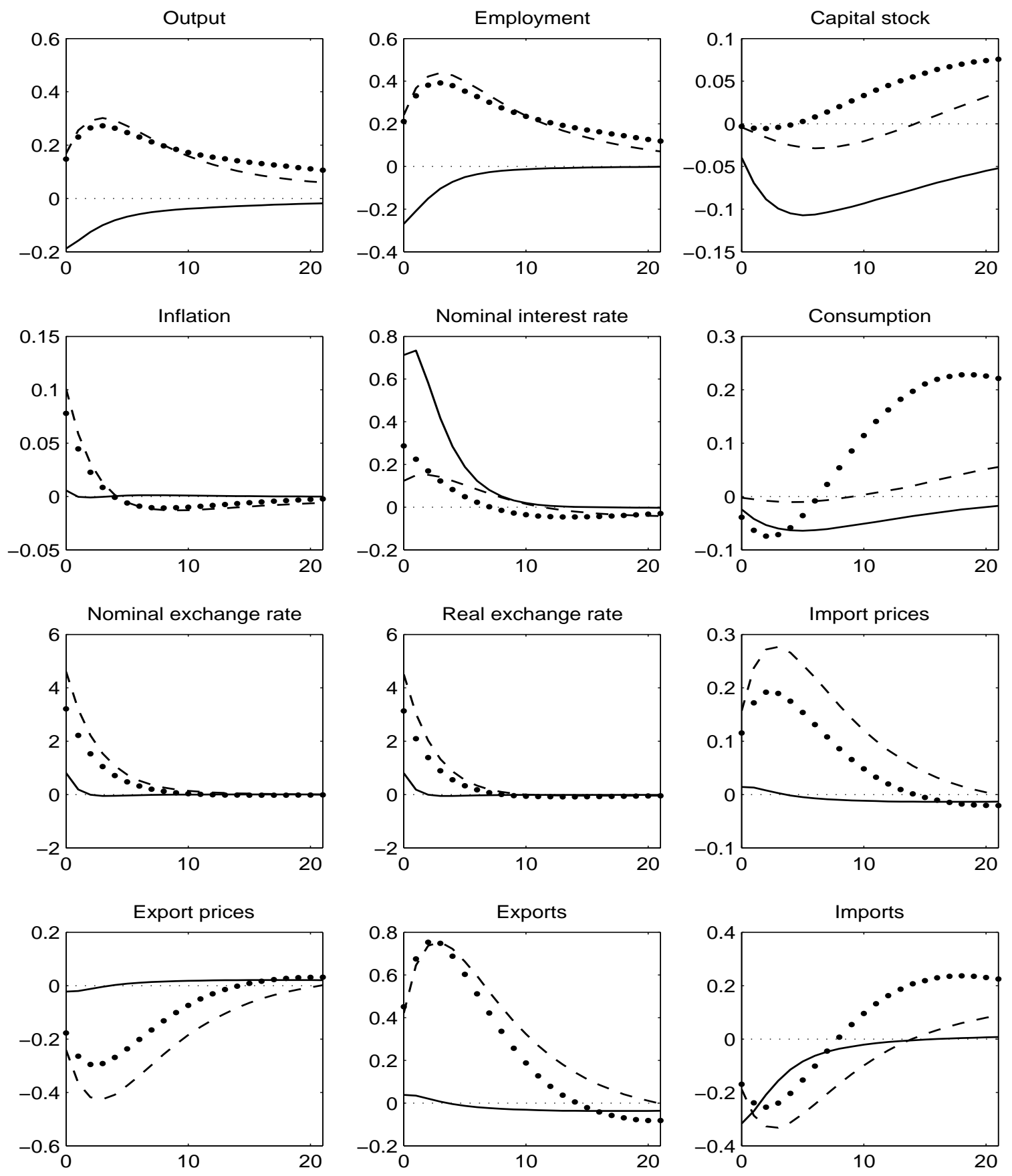
Figure 3: Responses to a labor supply shock. Solid line: TZ. Dotted line: IT. Dashed line: IT. Dotted line: NRC.
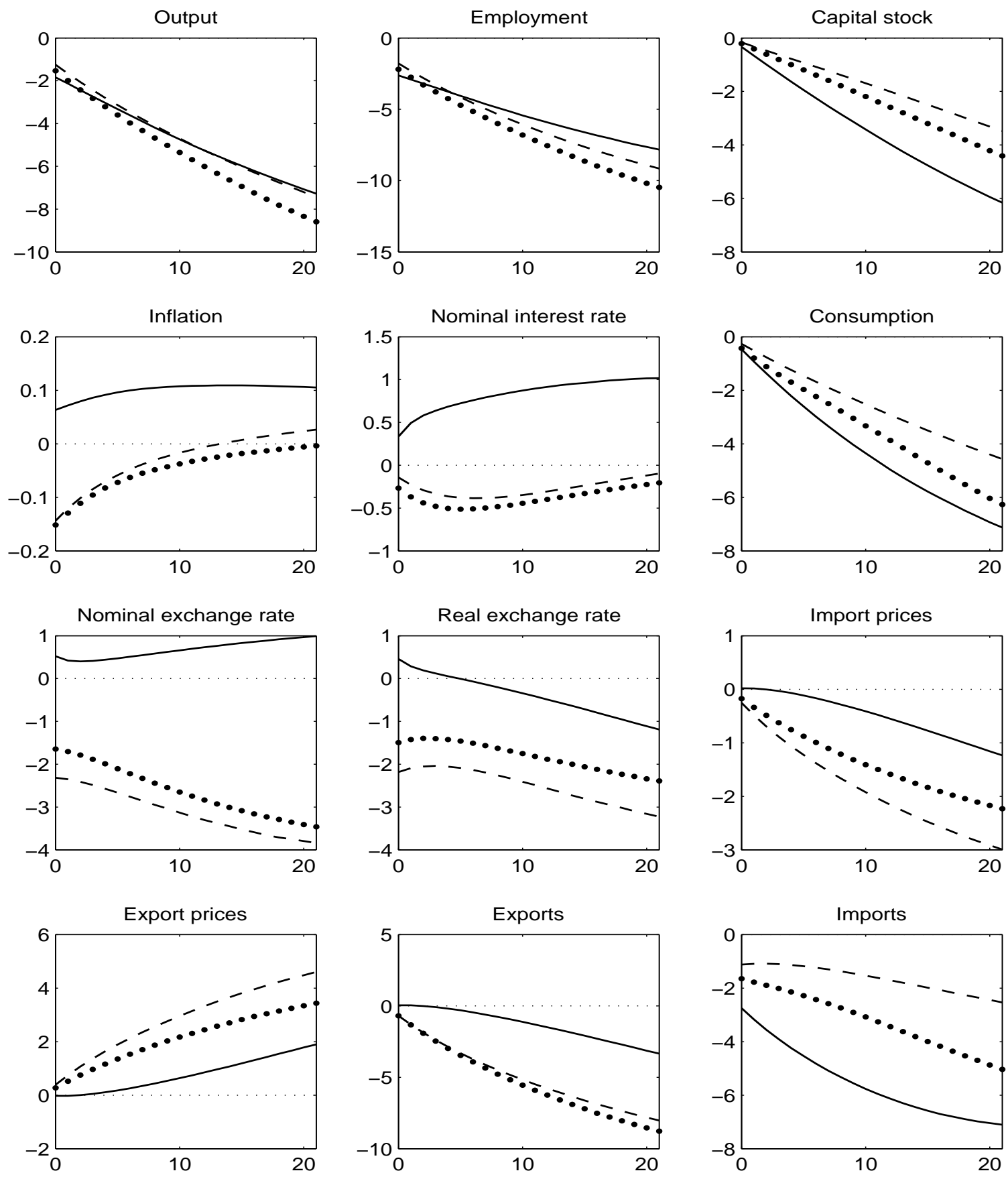
Figure 4: Responses to a technology shock. Solid line: TZ. Dashed line: IT. Dotted line: NRC
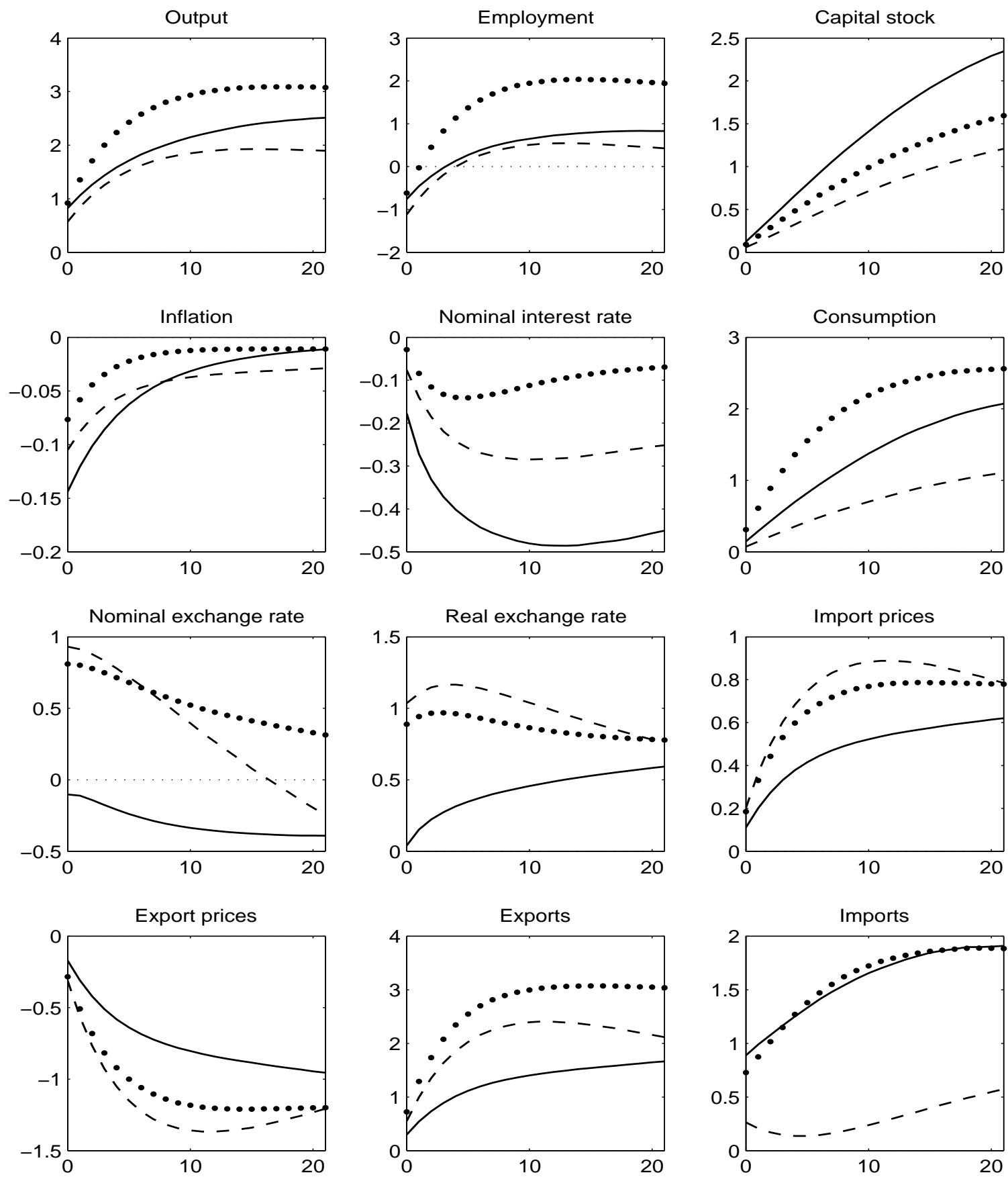
Figure 5: Responses to a monetary shock. Solid line: TZ. Dashed line: IT. Dotted line: NRC.
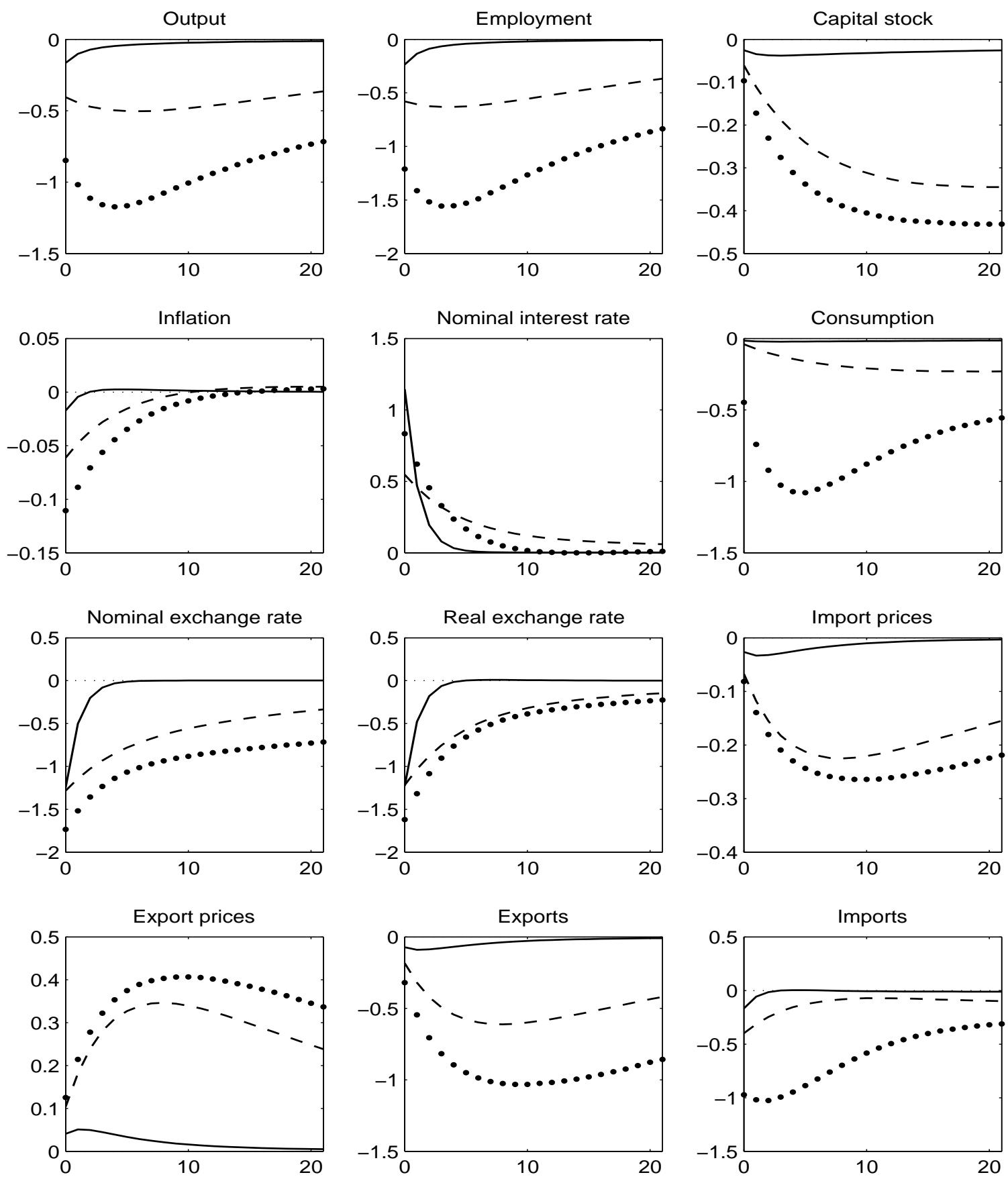
Figure 6: Evolution of some variables during the target zone period under the estimated policy for that period and under the estimated policy for the inflation targeting regime, with both the monetary policy and risk premium shock innovations shut down.
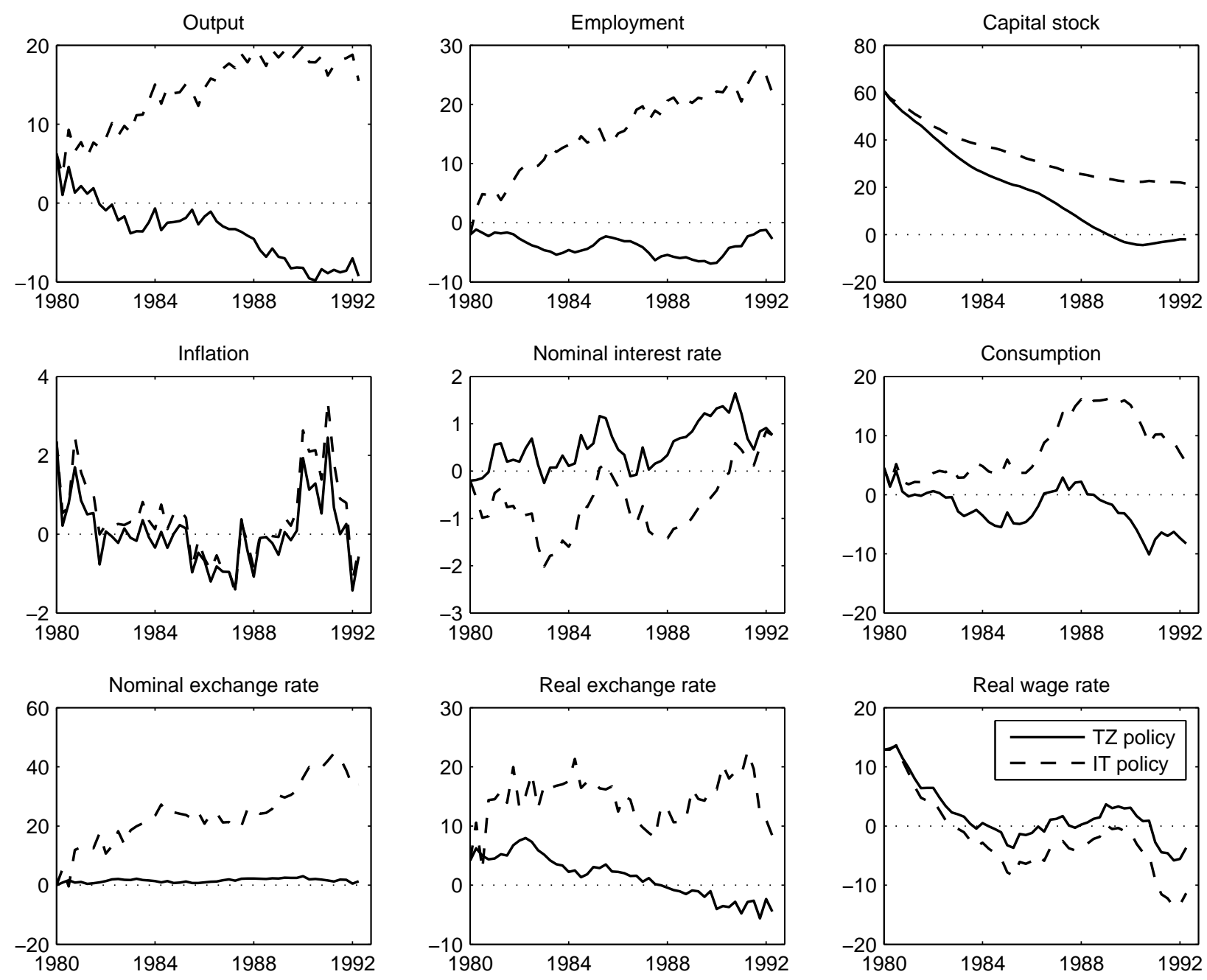


\section{Earlier Working Papers:}

For a complete list of Working Papers published by Sveriges Riksbank, see www.riksbank.se

Estimation of an Adaptive Stock Market Model with Heterogeneous Agents by Henrik Amilon ........ 2005:177

Some Further Evidence on Interest-Rate Smoothing: The Role of Measurement

Errors in the Output Gap by Mikael Apel and Per Jansson.....

Bayesian Estimation of an Open Economy DSGE Model with Incomplete Pass-Through

by Malin Adolfson, Stefan Laséen, Jesper Lindé and Mattias Villani

Are Constant Interest Rate Forecasts Modest Interventions? Evidence from

an Estimated Open Economy DSGE Model of the Euro Area by Malin Adolfson,

Stefan Laséen, Jesper Lindé and Mattias Villani

Inference in Vector Autoregressive Models with an Informative

Prior on the Steady State by Mattias Villani

Bank Mergers, Competition and Liquidity by Elena Carletti, Philipp Hartmann

and Giancarlo Spagnolo

Testing Near-Rationality using Detailed Survey Data

by Michael F. Bryan and Stefan Palmqvist.

Exploring Interactions between Real Activity and the Financial Stance

by Tor Jacobson, Jesper Lindé and Kasper Roszbach

Two-Sided Network Effects, Bank Interchange Fees,

and the Allocation of Fixed Costs by Mats A. Bergman .....

Trade Deficits in the Baltic States: How Long Will the Party Last?

by Rudolfs Bems and Kristian Jönsson.

Real Exchange Rate and Consumption Fluctuations follwing Trade Liberalization

by Kristian Jönsson

Modern Forecasting Models in Action: Improving Macroeconomic Analyses at Central Banks

by Malin Adolfson, Michael K. Andersson, Jesper Lindé, Mattias Villani and Anders Vredin.....

Bayesian Inference of General Linear Restrictions on the Cointegration Space by Mattias Villani.

2005:189

Forecasting Performance of an Open Economy Dynamic Stochastic General Equilibrium Model

by Malin Adolfson, Stefan Laséen, Jesper Lindé and Mattias Villani

Forecast Combination and Model Averaging using Predictive Measures

by Jana Eklund and Sune Karlsson.

Swedish Intervention and the Krona Float, 1993-2002

by Owen F. Humpage and Javiera Ragnartz

A Simultaneous Model of the Swedish Krona, the US Dollar and the Euro

by Hans Lindblad and Peter Sellin

Testing Theories of Job Creation: Does Supply Create Its Own Demand?

by Mikael Carlsson, Stefan Eriksson and Nils Gottfries.....

Down or Out: Assessing The Welfare Costs of Household Investment Mistakes

by Laurent E. Calvet, John Y. Campbell and Paolo Sodini

Efficient Bayesian Inference for Multiple Change-Point and Mixture Innovation Models

by Paolo Giordani and Robert Kohn

Derivation and Estimation of a New Keynesian Phillips Curve in a Small Open Economy

by Karolina Holmberg

Technology Shocks and the Labour-Input Response: Evidence from Firm-Level Data

by Mikael Carlsson and Jon Smedsaas

Monetary Policy and Staggered Wage Bargaining when Prices are Sticky

by Mikael Carlsson and Andreas Westermark

The Swedish External Position and the Krona by Philip R. Lane

Price Setting Transactions and the Role of Denominating Currency in FX Markets

by Richard Friberg and Fredrik Wilander.....

The geography of asset holdings: Evidence from Sweden

by Nicolas Coeurdacier and Philippe Martin

Evaluating An Estimated New Keynesian Small Open Economy Model

by Malin Adolfson, Stefan Laséen, Jesper Lindé and Mattias Villani .......

The Use of Cash and the Size of the Shadow Economy in Sweden

by Gabriela Guibourg and Björn Segendorf

Bank supervision Russian style: Evidence of conflicts between micro- and macro-

prudential concerns by Sophie Claeys and Koen Schoors 
Optimal Monetary Policy under Downward Nominal Wage Rigidity

by Mikael Carlsson and Andreas Westermark.

Financial Structure, Managerial Compensation and Monitoring

by Vittoria Cerasi and Sonja Daltung

Financial Frictions, Investment and Tobin's q by Guido Lorenzoni and Karl Walentin 2007:208

Sticky Information vs. Sticky Prices: A Horse Race in a DSGE Framework

by Mathias Trabandt 2007:209

Acquisition versus greenfield: The impact of the mode of foreign bank entry

on information and bank lending rates by Sophie Claeys and Christa Hainz

Nonparametric Regression Density Estimation Using Smoothly Varying Normal Mixtures

by Mattias Villani, Robert Kohn and Paolo Giordani

The Costs of Paying - Private and Social Costs of Cash and Card

by Mats Bergman, Gabriella Guibourg and Biörn Segendorf.

Using a New Open Economy Macroeconomics model to make real nominal

exchange rate forecasts by Peter Sellin....

Introducing Financial Frictions and Unemployment into a Small Open Economy Model

by Lawrence J. Christiano, Mathias Trabandt and Karl Walentin.

Earnings Inequality and the Equity Premium by Karl Walentin

Bayesian forecast combination for VAR models by Michael K Andersson and Sune Karlsson

$2007: 216$

Do Central Banks React to House Prices?

by Daria Finocchiaro and Virginia Queijo von Heideken.

The Riksbank's Forecasting Performance

by Michael K. Andersson, Gustav Karlsson and Josef Svensson

Macroeconomic Impact on Expected Default Freqency

by Per Åsberg and Hovick Shahnazarian .....

Monetary Policy Regimes and the Volatility of Long-Term Interest Rates

by Virginia Queijo von Heideken

Governing the Governors: A Clinical Study of Central Banks

by Lars Frisell, Kasper Roszbach and Giancarlo Spagnolo

The Monetary Policy Decision-Making Process and the Term Structure of Interest Rates

by Hans Dillén

How Important are Financial Frictions in the U.S. and the Euro Area

by Virginia Queijo von Heideken....

Block Kalman filtering for large-scale DSGE models by Ingvar Strid and Karl Walentin 2008:224

Optimal Monetary Policy in an Operational Medium-Sized DSGE Model

by Malin Adolfson, Stefan Laséen, Jesper Lindé and Lars E.O. Svensson $2008: 225$

Firm Default and Aggregate Fluctuations by Tor Jacobson, Rikard Kindell, Jesper Lindé and Kasper Roszbach

Re-Evaluating Swedish Membership in EMU: Evidence from an Estimated Model

by Ulf Söderström....

The Effect of Cash Flow on Investment: An Empirical Test of the Balance Sheet Channel

by Ola Melander

Expectation Driven Business Cycles with Limited Enforcement

by Karl Walentin

Effects of Organizational Change on Firm Productivity

by Christina Håkanson

Evaluating Microfoundations for Aggregate Price Rigidities: Evidence from Matched Firm-Level

Data on Product Prices and Unit Labor Cost by Mikael Carlsson and Oskar Nordström Skans 2009:231

Monetary Policy Trade-Offs in an Estimated Open-Economy DSGE Model

by Malin Adolfson, Stefan Laséen, Jesper Lindé and Lars E.O. Svensson....

Flexible Modeling of Conditional Distributions Using Smooth Mixtures of Asymmetric

Student T Densities by Feng Li, Mattias Villani and Robert Kohn.

Forecasting Macroeconomic Time Series with Locally Adaptive Signal Extraction

by Paolo Giordani and Mattias Villani......

Evaluating Monetary Policy by Lars E.O. Svensson 2009:235

Risk Premiums and Macroeconomic Dynamics in a Heterogeneous Agent Model

by Ferre De Graeve, Maarten Dossche, Marina Emiris, Henri Sneessens and Raf Wouters $2010: 236$

Picking the Brains of MPC Members by Mikael Apel, Carl Andreas Claussen and

Petra Lennartsdotter

Involuntary Unemployment and the Business Cycle by Lawrence J. Christiano,

Mathias Trabrandt and Karl Walentin

Housing collateral and the monetary transmission mechanism by Karl Walentin

and Peter Sellin

The Discursive Dilemma in Monetary Policy by Carl Andreas Claussen and Øistein Røisland. 
veriges Riksbank

Visiting address: Brunkebergs torg 11

Mail address: se-103 37 Stockholm

Website: www.riksbank.se

Telephone: +46878700 00, Fax: +468210531

E-mail: registratorn@riksbank.se 